\title{
A Novel Nicotinic Acetylcholine Receptor Subtype in Basal Forebrain Cholinergic Neurons with High Sensitivity to Amyloid Peptides
}

\author{
Qiang Liu, ${ }^{1}$ Yao Huang, ${ }^{3}$ Fenqin Xue, ${ }^{2}$ Alain Simard, ${ }^{2}$ Jamie DeChon, ${ }^{1}$ Guohui Li, ${ }^{1}$ Jianliang Zhang, ${ }^{2}$ Linda Lucero, ${ }^{2}$ \\ Min Wang, ${ }^{4}$ Michael Sierks, ${ }^{4}$ Gang Hu, ${ }^{5}$ Yongchang Chang, ${ }^{2}$ Ronald J. Lukas, ${ }^{2}$ and Jie $\mathrm{Wu}^{1}$ \\ Divisions of ${ }^{1}$ Neurology and ${ }^{2}$ Neurobiology, Barrow Neurological Institute, St. Joseph's Hospital and Medical Center, Phoenix, Arizona 85013-4496, \\ ${ }^{3}$ Department of Obstetrics and Gynecology, St. Joseph's Hospital and Medical Center, Phoenix, Arizona 85004, ${ }^{4}$ Department of Chemical Engineering, \\ Arizona State University, Tempe, Arizona 85281, and 5Department of Pharmacology, Nanjing Medical University, Nanjing 210029, People's Republic of \\ China
}

Nicotinic acetylcholine receptors (nAChRs) containing $\alpha 7$ subunits are thought to assemble as homomers. $\alpha 7$-nAChR function has been implicated in learning and memory, and alterations of $\alpha 7$-nAChR have been found in patients with Alzheimer's disease (AD). Here we report findings consistent with a novel, naturally occurring nAChR subtype in rodent, basal forebrain cholinergic neurons. In these cells, $\alpha 7$ subunits are coexpressed, colocalize, and coassemble with $\beta 2$ subunit(s). Compared with homomeric $\alpha 7$-nAChRs from ventral tegmental area neurons, functional, presumably heteromeric $\alpha 7 \beta 2$-nAChRs on cholinergic neurons freshly dissociated from medial septum/diagonal band (MS/DB) exhibit relatively slow kinetics of whole-cell current responses to nicotinic agonists and are more sensitive to the $\beta 2$ subunit-containing nAChR-selective antagonist, dihydro- $\beta$-erythroidine ( $\mathrm{DH} \beta \mathrm{E})$. Interestingly, presumed, heteromeric $\alpha 7 \beta 2$-nAChRs are highly sensitive to functional inhibition by pathologically relevant concentrations of oligomeric, but not monomeric or fibrillar, forms of amyloid $\beta_{1-42}\left(\mathrm{~A} \beta_{1-42}\right)$. Slow whole-cell current kinetics, sensitivity to $\mathrm{DH} \beta \mathrm{E}$, and specific antagonism by oligomeric $\mathrm{A} \beta_{1-42}$ also are characteristics of heteromeric $\alpha 7 \beta 2$-nAChRs, but not of homomeric $\alpha 7$-nAChRs, heterologously expressed in Xenopus oocytes. Moreover, choline-induced currents have faster kinetics and less sensitivity to A $\beta$ when elicited from MS/DB neurons derived from nAChR $\beta 2$ subunit knock-out mice rather than from wild-type mice. The presence of novel, functional, heteromeric $\alpha 7 \beta 2$-nAChRs on basal forebrain cholinergic neurons and their high sensitivity to blockade by low concentrations of oligomeric $\mathrm{A} \beta_{1-42}$ suggests possible mechanisms for deficits in cholinergic signaling that could occur early in the etiopathogenesis of $\mathrm{AD}$ and might be targeted by disease therapies.

Key words: nicotinic receptor; basal forebrain; cholinergic neurons; patch clamp; amyloid $\beta$; Alzheimer's disease

\section{Introduction}

Nicotinic acetylcholine receptors (nAChRs) in mammals exist as a diverse family of channels composed of different, pentameric combinations of subunits derived from at least 16 genes (Lukas et al., 1999; Jensen et al., 2005). Functional nAChRs can be assembled as either heteromers containing $\alpha$ and $\beta$ subunits or as homomers containing only $\alpha$ subunits (Lukas et al., 1999; Jensen et al., 2005). In the mammalian brain, the most abundant forms of nAChRs are heteromeric $\alpha 4 \beta 2$-nAChRs and homomeric $\alpha 7$ nAChRs (Whiting et al., 1987; Flores et al., 1992; Gopalakrishnan et al., 1996; Lindstrom, 1996; Lindstrom et al., 1996). $\alpha 7$-nAChRs appear to play roles in the development, differentiation, and

\footnotetext{
Received Aug. 19, 2008; revised Dec. 2, 2008; accepted Dec. 16, 2008.

This work was supported by an Arizona Alzheimer's Consortium Pilot grant, the Barrow Neurological Foundation, and the National Institutes of Health (R01 DA015389). We thank Kevin Ellsworth for his assistance in preparing this manuscript and Dr. Marina Picciotto (Yale University) for kindly providing the nAChR $\beta 2$ knock-out mice.

Correspondence should be addressed to Dr. Jie Wu, Division of Neurology, Barrow Neurological Institute, 350 West Thomas Road, Phoenix, AZ 85013-4496. E-mail: jie.wu@chw.edu.

D01:10.1523/JNEUROSCI.3952-08.2009

Copyright $\odot 2009$ Society for Neuroscience $\quad$ 0270-6474/09/290918-12\$15.00/0
}

pathophysiology of the nervous system (Z. Liu et al., 2007; Mudo et al., 2007).

nAChRs have been implicated in Alzheimer's disease (AD), in part because significant losses in radioligand binding sites corresponding to nAChRs have been consistently observed at autopsy in a number of neocortical areas and in the hippocampi of patients with AD (Burghaus et al., 2000; Nordberg, 2001). Attenuation of cholinergic signaling is known to impair memory, and nicotine exposure improves cognitive function in $\mathrm{AD}$ patients (Levin and Rezvani, 2002). In addition, several studies have suggested that the activation of $\alpha 7-\mathrm{nAChR}$ function alleviates amyloid- $\beta$ (A $\beta)$ toxicity. For instance, stimulation of $\alpha 7$ $\mathrm{nAChRs}$ inhibits amyloid plaque formation in vitro and in vivo (Geerts, 2005), activates $\alpha$-secretase cleavage of amyloid precursor protein (APP) (Lahiri et al., 2002), increases acetylcholine (ACh) release and facilitates $A \beta$ internalization (Nagele et al., $2002)$, inhibits activity of the MAPK/NF- $\kappa \mathrm{B} / \mathrm{c}-\mathrm{myc}$ signaling pathway (Q. Liu et al., 2007), and reduces $A \beta$ production and attenuates tau phosphorylation (Sadot et al., 1996). These findings suggest that cholinergic signaling, mediated through $\alpha 7$ - 
nAChRs, not only is involved in cognitive function, but also could protect against a wide variety of insults associated with $\mathrm{AD}$ (Sivaprakasam, 2006). Conversely, impairment of $\alpha 7$-nAChRmediated cholinergic signaling during the early stage(s) of AD might play a pivotal role in AD pathophysiology.

In rat basal forebrain cholinergic neurons, $\alpha 7$ and $\beta 2$ are the predominant $\mathrm{nAChR}$ subunits, and they were found to colocalize (Azam et al., 2003). Thus far, however, there has been no evidence that $\alpha 7$ and $\beta 2$ subunits coassemble to form functional nAChRs naturally, although functional $\alpha 7 \beta 2$-nAChRs have been reported using a heterologous expression system (Khiroug et al., 2002). We asked whether heteromeric $\alpha 7 \beta 2$-nAChRs exist in rodent basal forebrain cholinergic neurons and whether such a unique receptor subtype would be sensitive to $A \beta$. Using patchclamp electrophysiological, pharmacological, and molecular biological approaches, our findings demonstrate a novel partnership between $\mathrm{nAChR} \alpha 7$ and $\beta 2$ subunits, which likely assemble together to form a unique receptor subtype, and selectively high sensitivity of this novel nAChR subtype to pathologically relevant concentrations of $\mathrm{A} \beta$.

\section{Materials and Methods}

All techniques used in this manuscript are standard experimental approaches that are routinely performed in our laboratories, and the details of these techniques are available in our published papers (Wu et al., 2002, 2004a,b).

\section{Acutely dissociated neurons from the CNS and patch-clamp whole-cell current recordings}

Neuron dissociation and patch-clamp recordings were performed as described by Wu et al. $(2002,2004 b)$. Briefly, each postnatal 2- to 4 -weekold Wistar rat or mouse (wild-type C57BL/6 or nAChR $\beta 2$ knock-out mice on a C57BL/6 background kindly provided by Dr. Marina Picciotto, Yale University, New Haven, CT) was anesthetized using isoflurane, and the brain was rapidly removed. Several $400 \mu \mathrm{m}$ coronal slices, which contained the medial septum/diagonal band (MS/DB) or the ventral tegmental area (VTA), were cut using a vibratome (Vibratome 1000 plus; Jed Pella) in cold $\left(2-4^{\circ} \mathrm{C}\right)$ artificial CSF (ACSF) and continuously bubbled with carbogen $\left(95 \% \mathrm{O}_{2}-5 \% \mathrm{CO}_{2}\right)$. The slices were then incubated in a preincubation chamber (Warner Instruments) and allowed to recover for at least $1 \mathrm{~h}$ at room temperature $\left(22 \pm 1^{\circ} \mathrm{C}\right)$ in oxygenated ACSF. Thereafter, the slices were treated with Pronase $(1 \mathrm{mg} / 6 \mathrm{ml})$ at $31^{\circ} \mathrm{C}$ for 30 min and subsequently treated with the same concentration of thermolysin for another $30 \mathrm{~min}$. The MS/DB or VTA region was micropunched out from the slices using a well polished needle. Each punched piece was then dissociated mechanically by using several fire-polished microPasteur pipettes in a $35 \mathrm{~mm}$ culture dish filled with well oxygenated, standard external solution [in mM: $150 \mathrm{NaCl}, 5 \mathrm{KCl}, 1 \mathrm{MgCl}_{2}, 2 \mathrm{CaCl}_{2}, 10$ glucose, and 10 HEPES; pH 7.4 (with Tris-base)]. The separated single cells usually adhered to the bottom of the dish within $30 \mathrm{~min}$. Perforatedpatch whole-cell recordings coupled with a U-tube or two-barrel drug application system were used (Wu et al., 2002). Perforated-patch recordings more closely maintain both intracellular divalent cation and cytosolic element composition (Horn and Marty, 1988). In particular, perforated-patch recording was used to maintain the intracellular ATP concentration at a physiological level. To prepare for perforated-patch whole-cell recording, glass microelectrodes (GC-1.5; Narishige) were fashioned on a two-stage vertical pipette puller (P-830; Narishige), and the resistance of the electrode was 3-5 $\mathrm{M} \Omega$ when filled with the internal solution. A tight seal $(>2 \mathrm{G} \Omega$ ) was formed between the electrode tip and the cell surface, which was followed by a transition from on-cell to wholecell recording mode due to the partitioning of amphotericin B into the membrane underlying the patch. After whole-cell formation, an access resistance lower than $60 \mathrm{M} \Omega$ was acceptable during perforated-patch recordings in current-clamp mode, and an access resistance lower than $30 \mathrm{M} \Omega$ was acceptable during voltage-clamp recordings. The series resis- tance was not compensated in the experiments using dissociated neurons. Under current-clamp configuration, membrane potentials were measured using a patch-clamp amplifier (200B; Axon Instruments). Data were filtered at $2 \mathrm{kHz}$, acquired at $11 \mathrm{kHz}$, and digitized on-line (Digidata 1322 series A/D board; Axon Instruments). All experiments were performed at room temperature $\left(22 \pm 1^{\circ} \mathrm{C}\right)$. The drugs used in the present study were GABA, glutamate, $\mathrm{ACh}$, choline, methyllycaconitine (MLA), dihydro- $\beta$-erythroidine $(\mathrm{DH} \beta \mathrm{E})$, muscarine (all purchased from Sigma-Aldrich), RJR-2403 (purchased from Tocris Cookson), and $\mathrm{A} \beta_{1-42}$ and scrambled $\mathrm{A} \beta_{1-42}$ (purchased from rPeptide).

\section{RT-PCR to profile nAChR subunit expression in MS/DB}

Riboprobe construction

Templates for in vitro transcription were created using PCR and sense or antisense primers spanning the 5' SP6 promoter or the 3' T7 promoter, respectively $\quad\left(\alpha 7\right.$ subunit: $5^{\prime}$-atttaggtgacactatagaagnggatcatcgtgggcctctcagtg- $3^{\prime}$ and $5^{\prime}$-taatacgactcactatagggagagttggcgatgtagcggacctc- $3^{\prime}$; $\beta 2$ subunit: $5^{\prime}$-atttaggtgacactatagaagngtcacggtgttcctgctgctcatct- $3^{\prime}$ and $5^{\prime}$-taatacgactcactatagggagatcctccctcacactctggtcatca- $3^{\prime}$ ). Antisense or sense probes were then created by in vitro transcription using SP6 or T7 polymerases, respectively, and by incorporation of biotin-tagged UTP (for $\beta 2$ subunit probes) or digoxigenin-tagged UTP (for $\alpha 7$ subunit probes; biotin or digoxigenin RNA-labeling mix; Roche Applied Science). The $433 \mathrm{bp}$ or $520 \mathrm{bp}$ products corresponding to mRNA nucleotides $953-1385$ for $\alpha 7$ subunits or mRNA nucleotides $1006-1525$ for $\beta 2$ subunits thus produced are highly specific to the individual subunits.

\section{Tissue RT-PCR}

RT-PCR assays followed by Southern hybridization with nested oligonucleotides were done as previously described to identify nAChR subunit transcripts and to quantify levels of expression normalized both to housekeeping gene expression and levels of expression in whole brain (Wu et al., 2004), but using primers designed to detect rat nAChR subunits. The Southern hybridization technique coupled with quantitation using electronic isotope counting (Instant Imager, Canaberra Instruments) yielded results equivalent to those obtained using real-time PCR analysis.

\section{Single-cell RT-PCR}

Precautions were taken to ensure a ribonuclease-free environment and to avoid PCR product contamination during patch-clamp recording and single-cell collection before execution of RT-PCR. Single-cell RT-PCR was performed using the Superscript III CellDirect RT-PCR system (Invitrogen). Briefly, after whole-cell patch-clamp recording, single-cell content was harvested by suction into the pipette solution $(\sim 3 \mu \mathrm{l})$ and immediately transferred to an autoclaved $0.2 \mathrm{ml}$ PCR tube containing 10 $\mu l$ of cell resuspension buffer and $1 \mu \mathrm{l}$ of lysis enhancer. Single cells were lysed by heating at $75^{\circ} \mathrm{C}$ for $10 \mathrm{~min}$. Potential contaminating genomic DNA was removed by DNase I digestion at $25^{\circ} \mathrm{C}$ for $6 \mathrm{~min}$. After heatinactivation of DNaseI at $70^{\circ} \mathrm{C}$ for $6 \mathrm{~min}$ in the presence of EDTA, reverse transcription (RT) was performed by adding reaction mix with oligo(dT) 20 and random hexamers and SuperScriptIII enzyme mix and then incubating at $25^{\circ} \mathrm{C}$ for $10 \mathrm{~min}$ and $50^{\circ} \mathrm{C}$ for $50 \mathrm{~min}$. The reaction was terminated by heating the sample to $85^{\circ} \mathrm{C}$ for $5 \mathrm{~min}$. The PCR primers for glyceraldehyde-3-phosphate dehydrogenase (GAPDH) and nAChR $\alpha 3$, $\alpha 4, \alpha 7, \beta 2$, and $\beta 4$ subunits were designed using the Primer 3 internet server (http://frodo.wi.mit.edu/cgi-bin/primer3/primer3_www.cgi) and assuming an annealing temperature of $\sim 60^{\circ} \mathrm{C}$ [nearest neighbor]. PCR was performed with $20 \mu \mathrm{l}$ of hot-start Platinum PCR Supermix (Invitrogen), $3 \mu \mathrm{l}$ of cDNA template from the RT step, and $1 \mu$ l of gene specific primer pairs ( 5 pmol each) with the following thermocycling parameters: $95^{\circ} \mathrm{C}$ for $2 \mathrm{~min}$; $\left(95^{\circ} \mathrm{C}\right.$ for $30 \mathrm{~s}, 60^{\circ} \mathrm{C}$ for $30 \mathrm{~s}$, and $72^{\circ} \mathrm{C}$ for $\left.40 \mathrm{~s}\right) \times 70$ cycles, $72^{\circ} \mathrm{C}$ for $1 \mathrm{~min}$. PCR products were resolved on $1.5 \% \mathrm{TBE}$-agarose gels, and stained gels were used to visualize bands, using digital photography and a gel documentation system to capture images. 


\section{Tissue protein extraction, immunoprecipitation, and immunoblotting for confirmation of $\mathrm{AChR} \alpha 7$ and $\beta 2$ subunit coassembly}

Tissues were Dounce homogenized (10 strokes) in ice-cold lysis buffer [1\% (v/v) Triton X-100, $150 \mathrm{~mm}$ EDTA, 10\% (v/v) glycerol, $50 \mathrm{~mm}$ Tris- $\mathrm{HCl}, \mathrm{pH}$ 8.0] containing $1 \times$ general protease inhibitor cocktails (Sigma-Aldrich). The lysates were transferred to microcentrifuge tubes and further solubilized for $30 \mathrm{~min}$ at $4^{\circ} \mathrm{C}$. The detergent extracts (supernatants) were collected by centrifugation at $15,000 \times g$ for $15 \mathrm{~min}$ at $4^{\circ} \mathrm{C}$, and protein concentration was determined for sample aliquots using bicinchoninic acid (BCA) protein assay reagents (Pierce Chemical). The detergent extracts were then precleared with $50 \mu \mathrm{l}$ of mixed slurry of protein A-Sepharose and protein G-Sepharose (1:1) (Amersham Biosciences) twice, each for $30 \mathrm{~min}$ at $4^{\circ} \mathrm{C}$. For each immunoprecipitation, detergent extracts $(1 \mathrm{mg})$ were mixed with $1 \mu \mathrm{g}$ of rabbit anti- $\alpha 7$ antiserum (H302) or rabbit IgG (as immunological control) (Santa Cruz Biotechnology) and incubated at $4^{\circ} \mathrm{C}$ overnight with continuous agitation. Protein A-Sepharose and protein G-Sepharose mixtures $(50 \mu \mathrm{l})$ were added and incubated at $4^{\circ} \mathrm{C}$ for $1 \mathrm{~h}$. The beads were washed four times with ice-cold lysis buffer containing protease inhibitors. Laemmli sample buffer eluates were resolved by SDS-PAGE. Proteins were transferred onto Hybond ECL nitrocellular membranes (Amersham Biosciences). The membranes were blocked with TBST buffer $[20 \mathrm{~mm}$ Tris$\mathrm{HCl}, \mathrm{pH} 7.6,150 \mathrm{~mm} \mathrm{NaCl}$, and $0.1 \%(\mathrm{v} / \mathrm{v})$ Tween 20] containing $2 \%$ $(\mathrm{w} / \mathrm{v})$ nonfat dry milk for at least $2 \mathrm{~h}$ and incubated with rat monoclonal anti- $\beta 2$ antibody (mAb270; Santa Cruz) or anti- $\alpha 7$ antiserum (H302), respectively, at $4^{\circ} \mathrm{C}$ overnight. After three washes in TBST, the membranes were incubated with goat anti-rat or goat anti-rabbit secondary antibodies $(1: 10,000)$ (Pierce Chemical) for $1 \mathrm{~h}$ and washed. The bound antibodies were detected with SuperSignal chemiluminescent substrate (Pierce Chemical).

\section{Expression of homomeric and heteromeric $\alpha 7$-containing- nAChRs in Xenopus oocytes and two-electrode voltage-clamp recording}

cDNAs encoding rat $\alpha 7$ and $\beta 2$ subunits were amplified by PCR with pfuUltra DNA polymerase and subcloned into an oocyte expression vector, pGEMHE, with T7 orientation and confirmed by automated sequencing. cRNAs were synthesized by standard in vitro transcription with T7 RNA polymerase, confirmed by electrophoresis for their integrity, and quantified based on optical absorbance measurements using an Eppendorf Biophotometer.

\section{Oocyte preparation and $c R N A$ injection}

Xenopus laevis (Xenopus I) females were anesthetized using 0.2\% MS222. The ovarian lobes were surgically removed from the frogs and placed in an incubation solution consisting of (in $\mathrm{mm}$ ): $82.5 \mathrm{NaCl}, 2.5 \mathrm{KCl}, 1$ $\mathrm{MgCl}_{2}, 1 \mathrm{CaCl}_{2}, 1 \mathrm{Na}_{2} \mathrm{HPO}_{4}, 0.6$ theophylline, 2.5 sodium pyruvate, 5 HEPES, $50 \mathrm{mg} / \mathrm{ml}$ gentamycin, $50 \mathrm{U} / \mathrm{ml}$ penicillin, and $50 \mu \mathrm{g} / \mathrm{ml} \mathrm{strep-}$ tomycin; $\mathrm{pH}$ 7.5. The frogs were then allowed to recover from surgery before being returned to the incubation tank. The lobes were cut into small pieces and digested with 0.08 Wunsch $\mathrm{U} / \mathrm{ml}$ liberase blendzyme 3 (Roche Applied Science) with constant stirring at room temperature for $1.5-2 \mathrm{~h}$. The dispersed oocytes were thoroughly rinsed with incubation solution. Stage VI oocytes were selected and incubated at $16^{\circ} \mathrm{C}$ before injection. Micropipettes used for injection were pulled from borosilicate glass (Drummond Scientific). cRNAs encoding $\alpha 7$ or $\beta 2$ at proper dilution were injected into oocytes separately or in different ratios using a Nanoject microinjection system (Drummond Scientific) at a total volume of $\sim 20-60 \mathrm{nl}$.

\section{Two-electrode voltage-clamp recording}

One to three days after injection, an oocyte was placed in a small-volume chamber and continuously perfused with oocyte Ringer's solution (OR2), consisting of the following (in $\mathrm{mM}$ ): $92.5 \mathrm{NaCl}, 2.5 \mathrm{KCl}, 1 \mathrm{CaCl}_{2}$, $1 \mathrm{MgCl}_{2}$, and 5 HEPES; $\mathrm{pH}$ 7.5. The chamber was grounded through an agarose bridge. The oocytes were voltage clamped at $-70 \mathrm{mV}$ to measure ACh (or choline)-induced currents using GeneClamp 500B (Axon Instruments).

\section{Immunocytochemical staining}

Dissociated MS/DB neurons were fixed with 4\% paraformaldehyde for 5 min, rinsed three times with PBS, and treated with saponin $(1 \mathrm{mg} / \mathrm{ml})$ for $5 \mathrm{~min}$ as a permeabilizing agent. After rinsing four times with PBS, the neurons were incubated at room temperature in anti-choline acetyltransferase (ChAT) primary antibody (AB305; Chemicon International) diluted 1:400 in HBSS (supplemented with 5\% bovine serum albumin as a blocking agent) for $30 \mathrm{~min}$. Following another three rinses with PBS, a secondary antibody (anti-mouse IgG; Sigma-Aldrich) was applied at room temperature for $30 \mathrm{~min}$ (diluted 1:100). After rinsing a final three times with PBS, the labeled cells were visualized using a Zeiss fluorescence microscope (Zeiss), and images were processed using Photoshop (Adobe Systems). For double immunolabeling of $\alpha 7$ and $\beta 2$ subunits of nAChRs on single dissociated MS/DB neurons, we used the following antibodies: a rabbit antibody (AS-5631S, 1:400; R and D) against $\alpha 7$ subunit, a rat antibody against $\beta 2$ subunit (Ab24698, 1:500; Abcam), Alexa Fluor 594-conjugated anti-rabbit IgG, and Alexa Fluor 488conjugated anti-rat IgG (1:300; Invitrogen).

\section{$\mathrm{A} \boldsymbol{\beta}$ preparation and determination/monitoring of peptide forms}

\section{A $\beta$ preparation}

Amyloid $\beta$ peptides $\left(\mathrm{A} \beta_{1-42}\right.$, scrambled $\left.\mathrm{A} \beta_{1-42}\right)$ were purchased from rPeptide. As previously described (Wu et al., 2004a), some preparations involved reconstitution of $\mathrm{A} \beta$ peptides per vendor specifications in distilled water to a concentration of $100 \mu \mathrm{M}$, stored at $-20^{\circ} \mathrm{C}$, and used within $10 \mathrm{~d}$ of reconstitution. These thawed peptide stock solutions were used to create working dilutions (1-100 nM) in standard external solution before patch-clamp recording. Working dilutions were used within $4 \mathrm{~h}$ before being discarded. Atomic force microscopy (AFM) was used to define and analyze over time the morphology of prepared $\mathrm{A} \beta_{1-42}$. Aliquots of freshly prepared samples of $\mathrm{A} \beta_{1-42}$ diluted in standard external solution were spotted on freshly cleaved mica. After 2 min the mica was washed with $200 \mu$ l of deionized water, dried with compressed nitrogen, and completely air-dried under vacuum. Images were acquired in air using a multimode AFM nanoscope IIIA system (Veeco/Digital Instruments) operating in the tapping mode using silicon probes (Olympus).

\section{Protocols to obtain different forms of $A \beta_{1-42}$}

Different conditions were used to specifically prepare monomeric, oligomeric, or fibrillar forms of $\mathrm{A} \beta_{1-42}$.

Monomers. A $\beta_{1-42}$ was reconstituted in DMSO to a concentration of $100 \mu \mathrm{m}$ and stored at $-80^{\circ} \mathrm{C}$. For each use, an aliquot of stock sample was freshly thawed and diluted into standard extracellular solution as above just before patch recordings and used for no more than $4 \mathrm{~h}$. This protocol yielded a predominant, monomeric form [see supplemental Fig. $1 C$ (left), available at www.jneurosci.org as supplemental material].

Oligomers. A $\beta_{1-42}$ reconstituted in distilled water to a concentration of $100 \mu \mathrm{M}$ and stored at $-80^{\circ} \mathrm{C}$ was used within $7 \mathrm{~d}$ of reconstitution. Aliquots diluted in standard extracellular solution and used within $4 \mathrm{~h}$ yielded a predominantly oligomeric form [see supplemental Fig. $1 C$ (middle), available at www.jneurosci.org as supplemental material].

Fibrils. Aliquots of $\mathrm{A} \beta_{1-42}$ stock solution (water dissolved to $100 \mu \mathrm{M}$ ) were thawed and incubated at $37^{\circ} \mathrm{C}$ for $48 \mathrm{~h}$ at low $\mathrm{pH}(\mathrm{pH}=6.0)$. Working stocks diluted in standard extracellular solution yielded a predominantly fibrillar form [see supplemental Fig. 1C (right), available at www.jneurosci.org as supplemental material].

\section{Genotyping of the nAChR $\beta 2$ subunit knock-out mice}

Genomic DNA from mice newly born to heterozygotic, nAChR $\beta 2$ subunit knock-out parents was extracted from mouse tail tips by using the QIAgen DNeasy Blood \& Tissue Kit following the manufacture's protocol. PCR amplification of the $\mathrm{nAChR} \beta 2$ subunit or lac-Z (an indicator for the knock-out) were performed using the purified genomic DNA as template and gene specific primer pairs (forward primer: CGG AGC ATT TGA ACT CTG AGC AGT GGG GTC GC; backward primer: CTC GCT GAC ACA AGG GCT GCG GAC; lac-Z forward primer: CAC TAC GTC TGA ACG TCG AAA ACC CG; backward primer: CGG GCA AAT AAT 

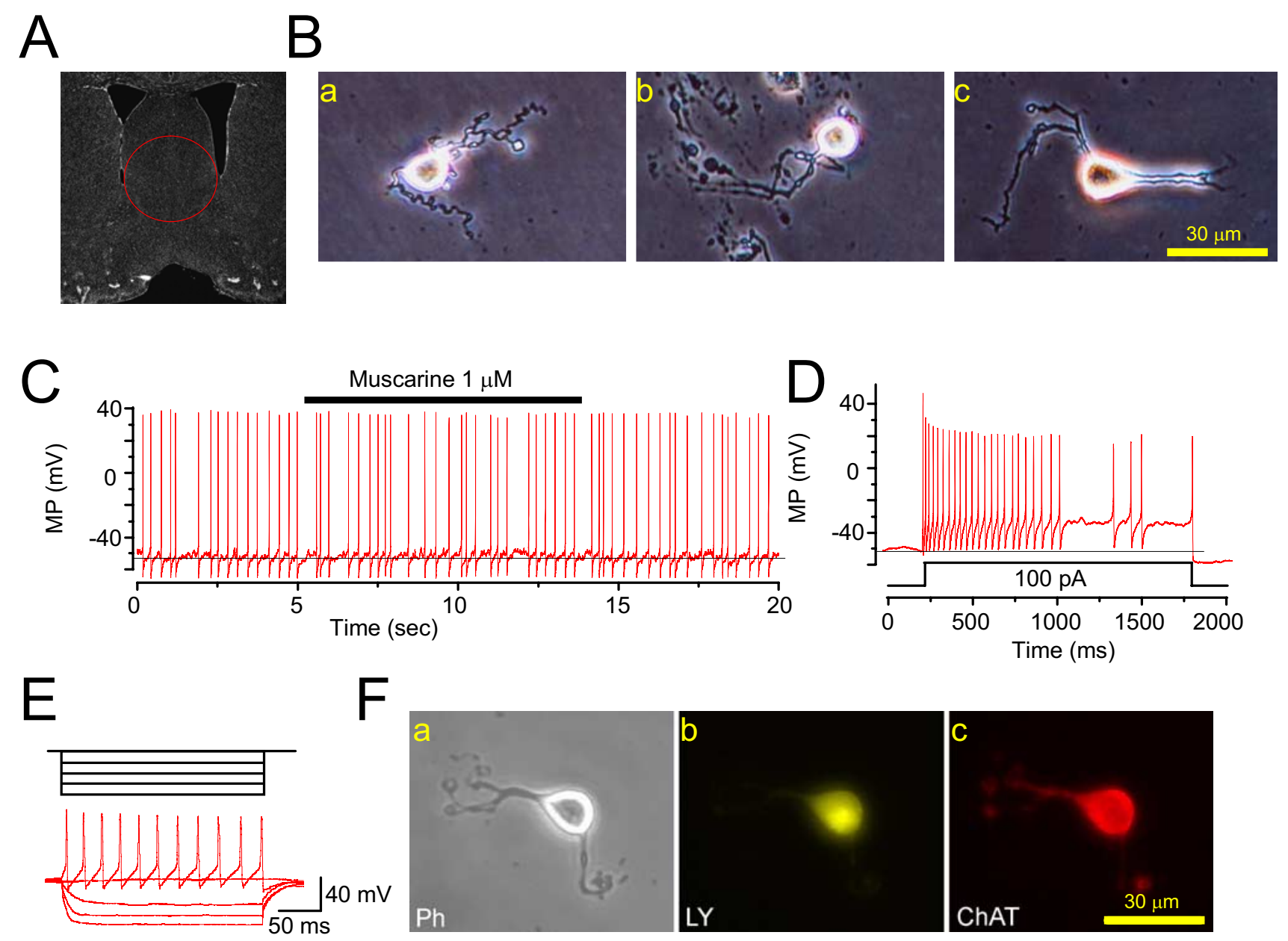

Figure 1. Identification of cholinergic neurons dissociated from basal forebrain. $A$, Phase-contrast image of a rat MS/DB brain slice [region confirmed according to the work of Paxinos and Watson (1986)]. MS/DB neurons (phase-contrast images of dissociated neurons; $\boldsymbol{B}$ ) exhibited spontaneous action potential firing $(\boldsymbol{C})$, insensitivity to muscarine $(\boldsymbol{C})$, and action potential adaptation induced by depolarizing pulses $(\boldsymbol{D})$ and did not show "sag"-like responses to hyperpolarizing pulses $(\boldsymbol{E})$, suggesting they were cholinergic. MP, Membrane potential. $\boldsymbol{F}$, Dissociated neuron (phase contrast, $\mathrm{Ph}$ ) labeled with lucifer yellow (LY) showed positive ChAT immunostaining following patch-clamp recording.

ATC GGT GGC CGT GG) with annealing at $55^{\circ} \mathrm{C}$ for 1 min and extension at $72^{\circ} \mathrm{C}$ for $1 \mathrm{~min}$ for 30 cycles with GO TaqDNA polymerase (Promega). PCR products were resolved on $1 \%$ agarose gels and stained for visualization before images were captured using digital photography.

\section{Results}

\section{Identification of cholinergic neurons dissociated from} basal forebrain

An initial series of experiments identified cholinergic neurons acutely dissociated from rat MS/DB (Fig. $1 A$ ). First, we identified the cholinergic phenotype of acutely dissociated neurons from the MS/DB (Fig. $1 B a-c$ ) based on published criteria (Henderson et al., 2005; Thinschmidt et al., 2005). In current-clamp mode, MS/DB neurons exhibited spontaneous action potential firing at low frequency $(2.3 \pm 0.4 \mathrm{~Hz}, n=25$ from 21 rats $)$. This spontaneous activity was insensitive to the muscarinic acetylcholine receptor agonist, muscarine $(1 \mu \mathrm{M})$ (Fig. 1C). Depolarizing pulses induced adaptation of action potential firing (Fig. 1D), and hyperpolarizing pulses failed to induce "sag"-like membrane potential changes (Fig. $1 E$ ). In some cases, the fluorescent dye lucifer yellow $(0.5 \mathrm{mg} / \mathrm{ml})$ was delivered into recorded cells after patchclamp recordings, and choline acetyltransferase (ChAT) immunocytostaining was used post hoc (Fig. $1 F$ ). The presence of ChAT immunoactivity in recorded, dye-filled neurons confirmed that dissociated MS/DB neurons were cholinergic.

\section{Naturally occurring $\mathrm{nAChRs}$ in rodent forebrain cholinergic neurons}

We next tested for the presence of functional nAChRs on MS/DB cholinergic neurons. Under voltage-clamp recording conditions, rapid application of $1 \mathrm{~mm} A \mathrm{ACh}$ induced inward current responses with relatively rapid activation and desensitization kinetics (Fig. $2 A)$. These ACh-induced responses were mimicked by application of the selective $\alpha 7-\mathrm{nAChR}$ agonist choline, blocked by the relatively selective $\alpha 7-\mathrm{nAChR}$ antagonist methyllycaconitine (MLA), and insensitive to the relatively selective $\alpha 4 \beta 2$-nAChR agonist RJR-2403 (Fig. 2A). Thus, the inward current evoked in MS/DB neurons had features similar to receptors containing $\alpha 7$ subunits. In contrast, in acutely dissociated, dopaminergic (DAergic) neurons from the midbrain VTA, ACh-induced currents displayed a mixture of features that could be dissected pharmacologically and with regard to whole-cell current kinetics. Components of responses displaying slow kinetics and sustained, steady-state currents elicited by ACh were mimicked by RJR2403 , suggesting that they were mediated by $\alpha 4 \beta 2$-nAChRs, whereas choline only induced transient peak current responses with very fast kinetics that are characteristic of homomeric $\alpha 7$ nAChRs (Fig. 2B). Interestingly, choline-induced currents in MS/DB cholinergic neurons exhibited relatively slow macroscopic kinetics than observed in VTA DAergic neurons (Fig. 2C). 

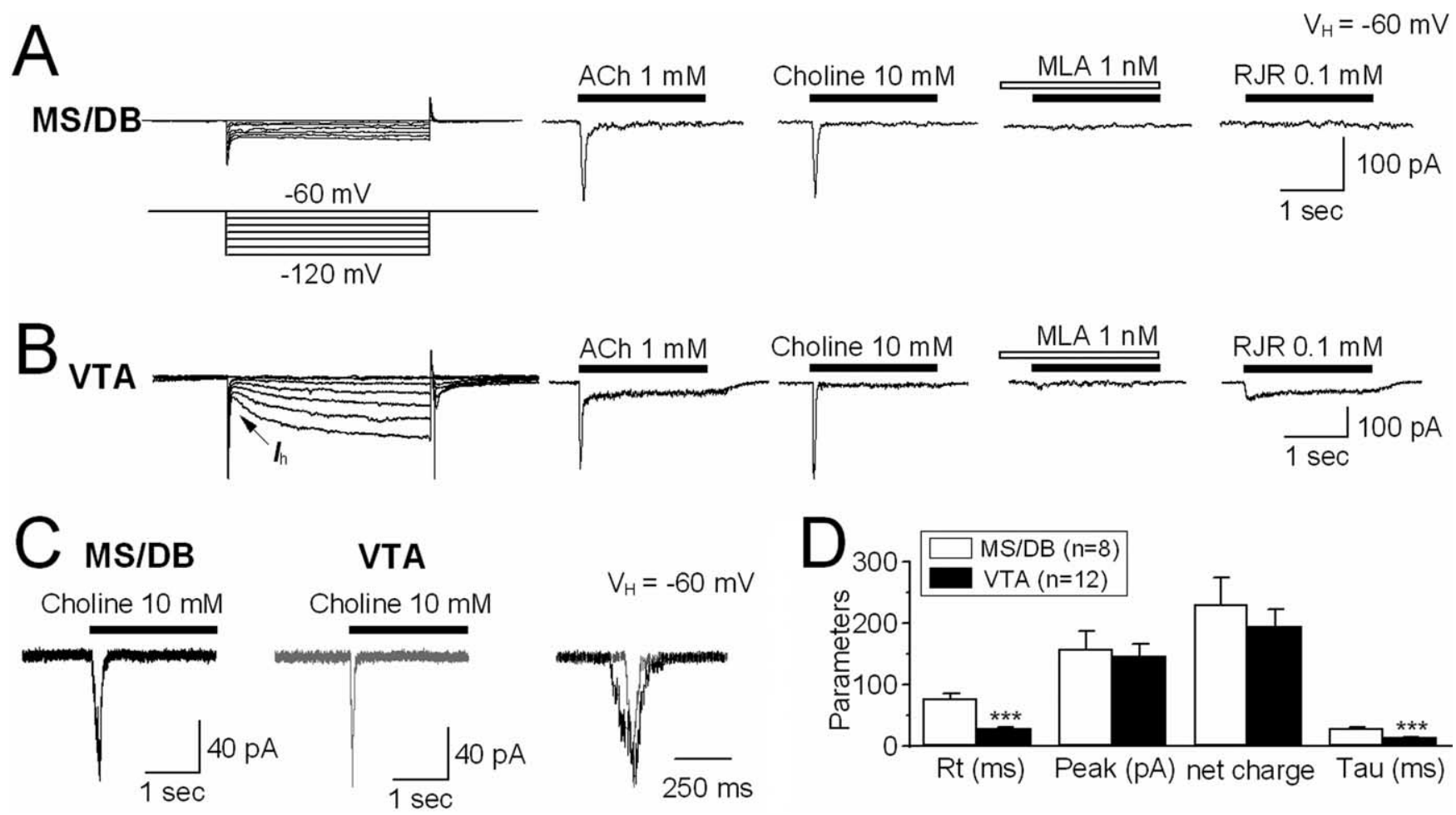

Figure 2. Native nAChR-mediated whole-cell current responses. An identified MS/DB cholinergic neuron (no hyperpolarization-induced current, $/ \mathrm{h}$ ) exhibited $\alpha 7$-nAChR-like current responses to $1 \mathrm{~mm}$ ACh and $10 \mathrm{~mm}$ choline (sensitive to blockade by $1 \mathrm{~nm}$ methyllycaconitine; MLA) but not to $0.1 \mathrm{~mm}$ RJR-2403, an agonist selective for $\alpha 4 \beta 2$-nAChRs (A), whereas an identified VTA DAergic neuron (evident $I_{\mathrm{h}}$ ) showed both $\alpha 7$-nAChR-like (i.e., choline and MLA-sensitive components) and $\alpha 4 \beta 2$-nAChR-like (i.e., RJR-2403-sensitive component) current responses (summed as in the response to $A(h)(B)$. C, Typical traces of $10 \mathrm{~mm}$ choline-induced currents in MS/DB and VTA DAergic neurons showing different kinetics for current activation/desensitization with a slower response characteristic of MS/DB neurons. D, Statistical comparisons of kinetics of $10 \mathrm{~mm}$ choline-induced currents in MS/DB cholinergic and VTA DAergic neurons. ${ }^{* * *} p<0.001$.

This impression was confirmed by quantitative analyses, which gave values for current rising time of $72.1 \pm 9.1 \mathrm{~ms}(n=8)$ for $\mathrm{MS} / \mathrm{DB}$ neurons and $29.1 \pm 2.9 \mathrm{~ms}(n=12)$ for VTA neurons $(p<0.001)$ and decay constants $(\tau$, rate of decay from peak to steady-state current) of $28.6 \pm 2.8 \mathrm{~ms}(n=8)$ for MS/DB neurons and $10.2 \pm 1.5 \mathrm{~ms}(n=12)$ for VTA neurons $(p<0.001)$. There were no significant differences between either peak current amplitudes or net charge movements for responses elicited by choline in MS/DB or VTA neurons (Fig. 2D). These results suggested that functional nAChRs naturally expressed on rat MS/DB cholinergic neurons with some features like $\alpha 7$-nAChRs had slower whole-cell current kinetics than found for $\alpha 7$-nAChR-like responses in VTA DAergic neurons.

\section{Subunit partnership for naturally occurring nAChRs in rodent basal forebrain cholinergic neurons}

To test the hypothesis that the relatively slow kinetics of $\alpha 7$ nAChR-like responses in MS/DB cholinergic neurons were due to coassembly of $\alpha 7$ with other nAChR subunits, we performed relative quantitative RT-PCR analysis of nAChR subunit expression as messenger RNA in MS/DB compared with whole-brain and VTA tissues. The results demonstrated that nAChR $\alpha 7$ and $\beta 2$ subunits were among those coexpressed regionally (Fig. $3 A, B)$. These studies were extended to single-cell RT-PCR analysis of nAChR subunit expression in acutely dissociated neurons from the MS/DB used in patch-clamp recordings (Fig. $3 \mathrm{Ca}-\mathrm{c}$ ). Quantitative analysis indicated a high frequency of nAChR $\alpha 7$ and $\beta 2$ subunit coexpression as message in recorded MS/DB neurons (Fig. $3 C d$ ). Mindful of the current concerns about the specificity of all anti-nAChR subunit antibodies (Moser et al., 2007), we nevertheless showed qualitatively, based on dual-labeling im- munofluorescent staining (Fig. 3D), that $\alpha 7$ and $\beta 2$ subunits were colocalized in many MS/DB neurons subjected to patchclamp recording. More direct evidence for coassembly of nAChR $\alpha 7$ and $\beta 2$ subunit proteins came from coimmunoprecipitation studies using subunit-specific antibodies. Protein extracts from rat MS/DB or VTA tissues (collected from rats aged between 18 and $22 \mathrm{~d}$ ) were subjected to immunoprecipitation (IP) (Fig. 3E, left) with a rabbit anti-nAChR $\alpha 7$ subunit antibody (H302) or with rabbit IgG (as an immunological control) followed by immunoblotting (IB) with a rat anti-nAChR $\beta 2$ subunit monoclonal antibody (mAb270). As indicated, the $\beta 2$ subunit was readily detected immunologically in anti- $\alpha 7$ immunoprecipitates from MS/DB but not from VTA regions under our experimental conditions (Fig. 3E, top left, lane 1 vs 2). Reprobing the same blot with the rabbit anti- $\alpha 7$ antibody (H302) verified that similar amounts of $\alpha 7$ subunits were precipitated from both MS/DB and VTA regions (Fig. 3E, bottom left, lanes 1 and 2). Thus, coprecipitation of nAChR $\alpha 7$ and $\beta 2$ subunits appeared only in samples from the rat MS/DB but not from the VTA. Collectively, these results suggest that $\mathrm{nAChR} \alpha 7$ and $\beta 2$ subunits are most likely coassembled, perhaps to form a functional nAChR subtype, in rodent basal forebrain cholinergic neurons.

\section{Pharmacological profiles of functional $\mathrm{nAChRs}$ in rat forebrain cholinergic neurons}

Pharmacological approaches were used to compare features of functional nAChRs in MS/DB cholinergic or VTA DAergic neurons. The $\alpha 7$-nAChR-selective antagonist, MLA showed similar antagonist potency toward choline-induced currents in either MS/DB (Fig. 4Aa) or VTA (Fig. 4Ab) neurons. Analysis of concentration-inhibition curves (Fig. $4 A c$ ) yielded $\mathrm{IC}_{50}$ values 

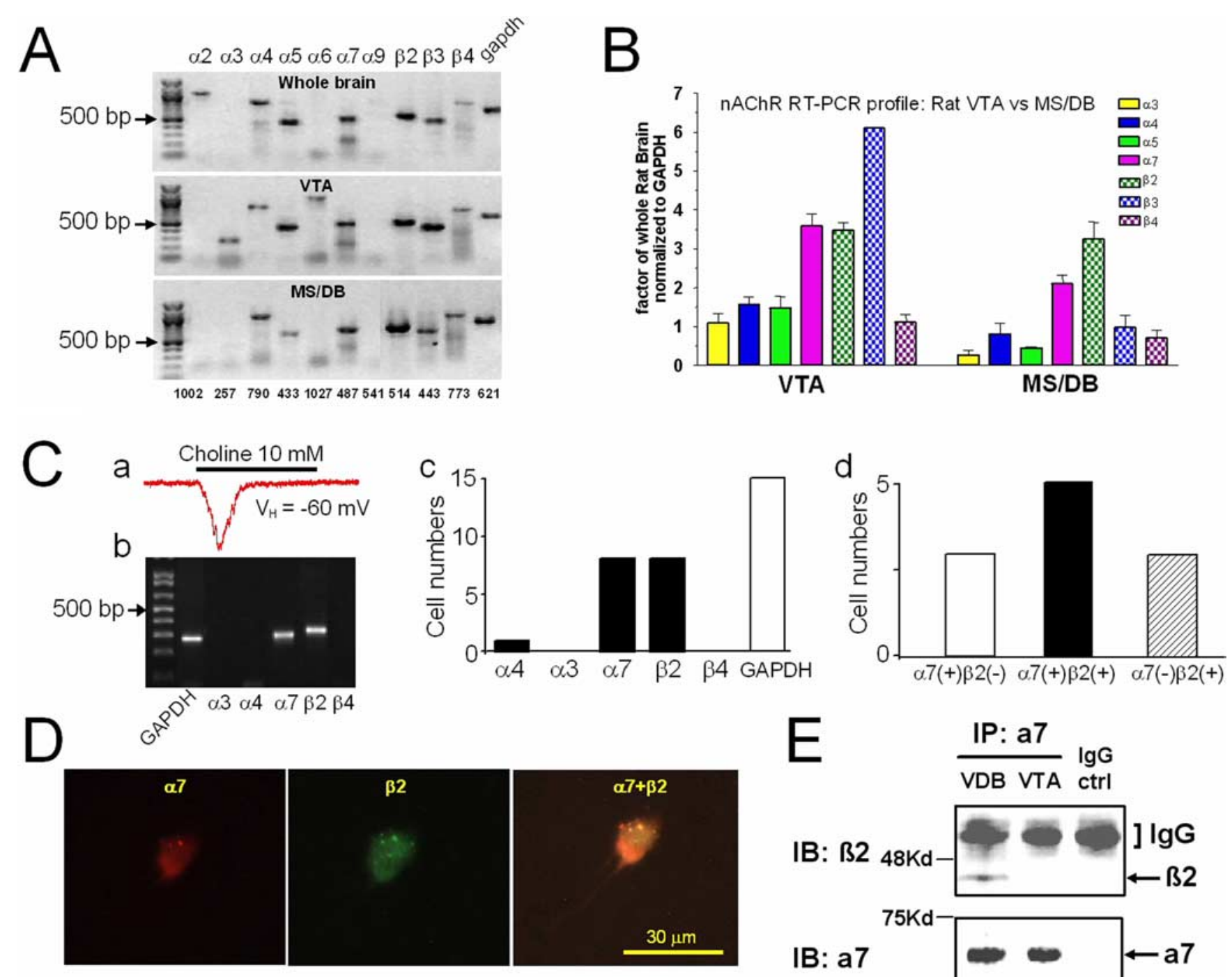

Figure 3. $\mathrm{nAChR} \alpha 7$ and $\beta 2$ subunits are coexpressed, colocalize, and coassemble in rat forebrain MS/DB neurons. RT-PCR products from whole brain and VTA and MS/DB regions ( $A$ ) corresponding to the indicated nAChR subunits or to the housekeeping gene GAPDH were resolved on an agarose gel calibrated by the flanking 100 bp ladders (heavy band is $500 \mathrm{bp}$ ) and visualized using ethidium staining. Note that the representative gel shown for whole brain did not contain a sample for the nAChR $\alpha 3$ subunit RT-PCR product, which typically is similar in intensity to the sample on the gel for the VTA and MS/DB. B, Quantification of nAChR subunit mRNA levels for RT-PCR amplification followed by Southern hybridization with ${ }^{32}$ P-labeled, nested oligonucleotides normalized to the GAPDH internal control and to levels of each specific mRNA in whole rat brain (ordinate: \pm SEM) for the indicated subunits. C, From 15 MS/DB neurons tested, after patch-clamp recordings (Ca: representative whole-cell current trace), the cell content was harvested and single-cell RT-PCR was performed, and the results show that $\alpha 7$ and $\beta 2$ were the two major nAChR subunits naturally expressed in MS/DB cholinergic neurons ( $\boldsymbol{C b}$ - $\mathbf{C d}$ ). Double immunofluorescence labeling of a MS/DB neuron with anti- $\alpha 7$ and anti- $\beta 2$ subunit antibodies revealed that $\alpha 7$ and $\beta 2$ subunit proteins colocalized, and similar results were obtained using 31 neurons from 12 rats (D). Protein extracts from rat MS/DB (lane 1) or rat VTA (lane 2) or from MS/DB from nAChR $\beta 2$ subunit knock-out (lane 4) or wild-type mice (lane 5) were immunoprecipitated (IP) with a rabbit anti- $\alpha 7$ antibody (Santa Cruz H302; lanes 1, 2, 4, and 5) or rabbit lgG as a control (lane 3). The eluted proteins from the precipitates were analyzed by immunoblotting (IB) with rat monoclonal anti- $\beta 2$ subunit antibody mAb270 (top) or rabbit anti- $\alpha 7$ antiserum H302 (bottom). The $\beta 2$ and $\alpha 7$ bands are indicated by arrows (E). All these data suggested that $\mathrm{nAChR} \alpha 7$ and $\beta 2 \mathrm{nAChR}$ subunits are coassembled in MS/DB neurons.

and Hill coefficients of $0.7 \mathrm{nM}$ and 1.1 , respectively, for MS/DB neurons $(n=8)$ and $0.4 \mathrm{nM}$ and 1.2 , respectively, for VTA neurons $(n=9, \mathrm{MS} / \mathrm{DB}$ vs VTA $p>0.05)$. However, the $\beta 2^{*}$ $\mathrm{nAChR}$-selective antagonist, $\mathrm{DH} \beta \mathrm{E}$ was $\sim 500$-fold less potent as an inhibitor of choline-induced current in MS/BD neurons (Fig. $4 \mathrm{Ba}$ ) than in VTA neurons (Fig. $4 \mathrm{Bb}$ ). $\mathrm{IC}_{50}$ values and Hill coefficients for $\mathrm{DH} \beta \mathrm{E}$-induced inhibition were $0.17 \mu \mathrm{M}$ and 0.9 , respectively, for MS/DB neurons $(n=8)$, and $>100 \mu \mathrm{M}$ and 0.3 , respectively, for VTA neurons $(n=7$; MS/DB vs VTA, $p<0.001)$ (Fig. $4 B c$ ). These results are consistent with the hypothesis that functional $\alpha 7^{\star}$-nAChRs on MS/DB cholinergic neurons also contain $\mathrm{DH} \beta \mathrm{E}$-sensitive $\beta 2$ subunits.
Functional $\mathrm{nAChRs}$ on rat basal forebrain cholinergic neurons are inhibited by $A \boldsymbol{\beta}_{1-42}$

Currently, it is not clear why basal forebrain cholinergic neurons are particularly sensitive to degeneration in $\mathrm{AD}$. To test the hypothesis that novel $\alpha 7 \beta 2$-nAChRs on MS/DB cholinergic neurons are involved, we determined the effects of $A \beta_{1-42}$ on these receptors. The experimental protocol involved repeated, acute challenges with $10 \mathrm{~mm}$ choline, and control studies in the absence of peptide demonstrated that there was no significant rundown of such responses when spaced at a minimum of 2 min intervals (Fig. 5Aa). During a continuous exposure to $1 \mathrm{nM} \mathrm{A} \beta_{1-42}$ starting just after an initial choline challenge and continuing for $10 \mathrm{~min}$, 

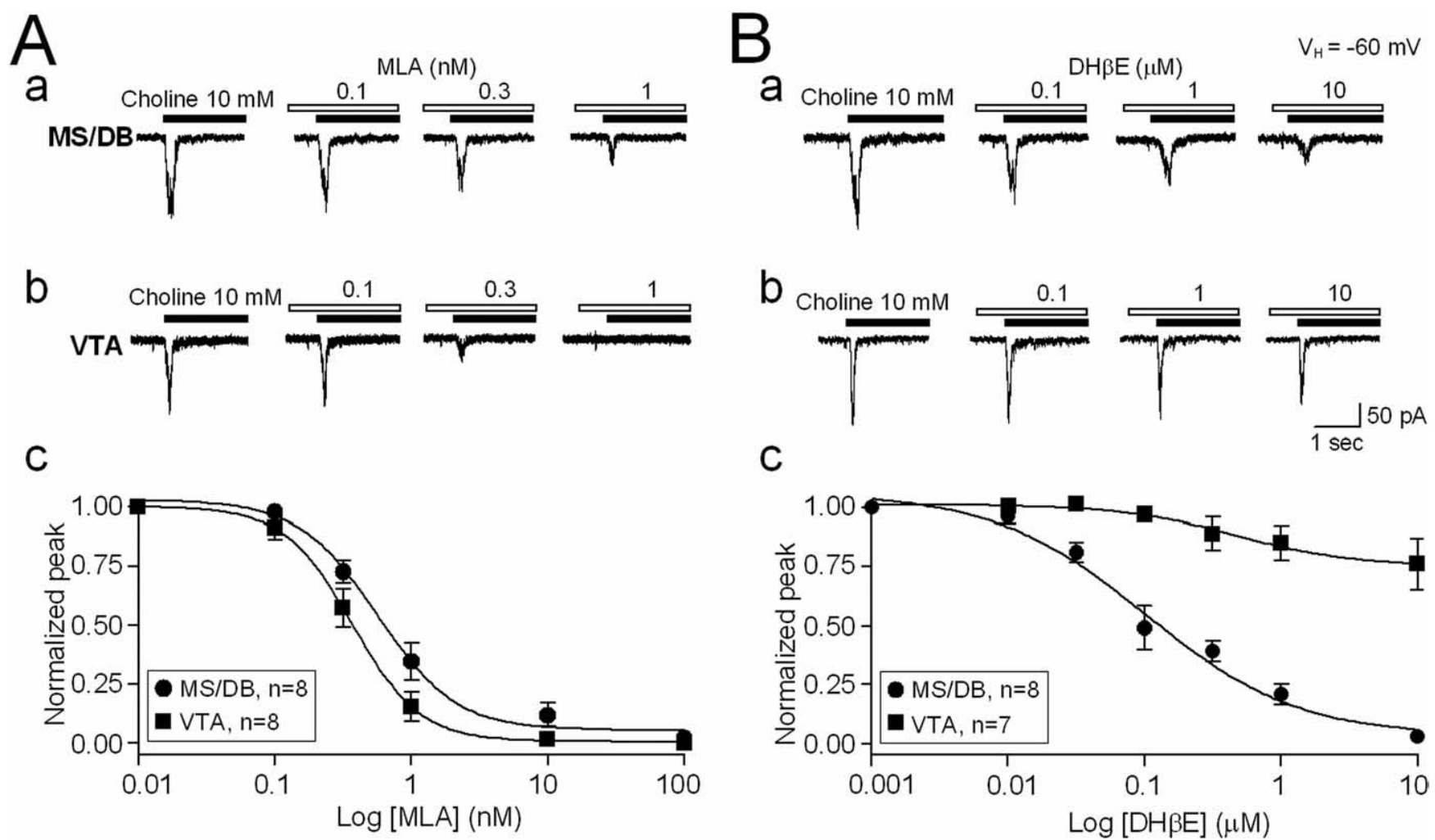

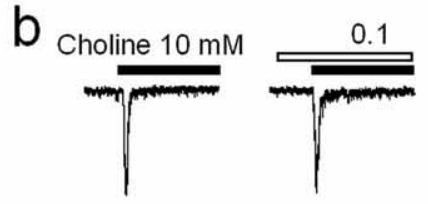

C
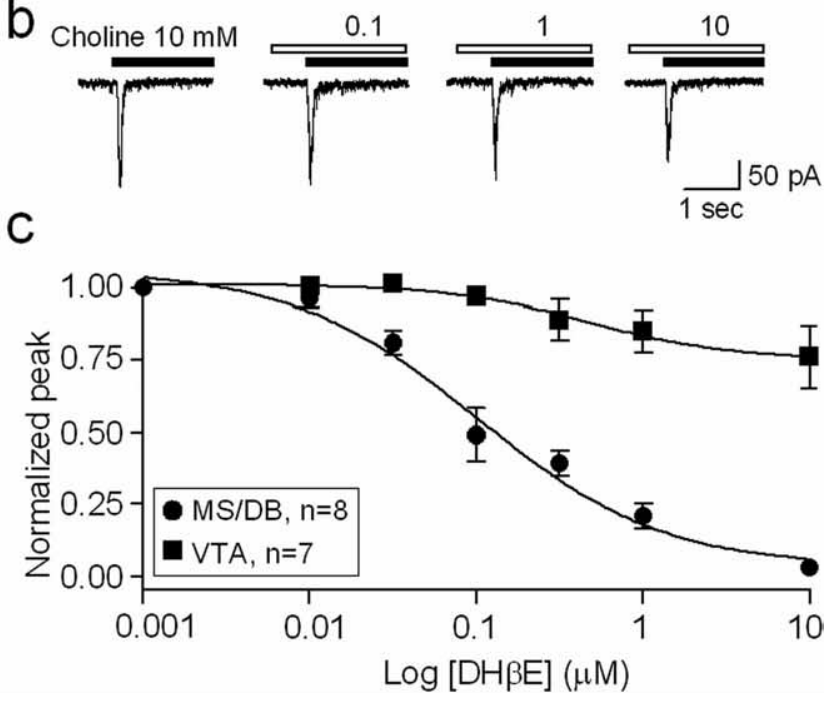

Figure 4. Antagonist profiles for MS/DB and VTA nAChRs. Concentration-dependent block by MLA (at the indicated concentrations in nm after preexposure for 2 min and continued exposure during agonist application indicated by open bars) of $10 \mathrm{~mm}$ choline-induced (applied as indicated by closed bars) whole-cell currents (representative traces shown) in MS/DB (Aa) and VTA (Ab) neurons was not significantly different $(p>0.05, \boldsymbol{A c}$ ). However, choline-induced currents in MS/DB neurons ( $\boldsymbol{B} \boldsymbol{a}$ ) were more sensitive to block by DH $\beta \mathrm{E}$ (at the indicated concentrations in $\mu \mathrm{m}$ after preexposure for 2 min and continued exposure during agonist application indicated by open bars) than in VTA neurons ( $\boldsymbol{B} \boldsymbol{b}$; concentration-response profile shown in $\boldsymbol{B} \boldsymbol{c})$. $\mathrm{V}_{\mathrm{H}}$, Holding potential.

responses to choline challenges were progressively inhibited with time, although reversibly so as demonstrated by response recovery after 6 min of peptide washout (Fig. $5 A b$ ). In contrast, exposure to 1 nM scrambled $\mathrm{A} \beta_{1-42}$ (as a control peptide) had no effect (Fig. 5Ac). Choline-induced currents in dissociated VTA DAergic neurons were not sensitive to $1 \mathrm{nM} \mathrm{A} \beta_{1-42}$ treatment (Fig. 5Ad). Quantitative analysis of several replicate experiments (Fig. $5 B$ ) confirmed that $\mathrm{A} \beta_{1-42}$, even at $1 \mathrm{nM}$ concentration, specifically inhibits putative $\alpha 7 \beta 2$-nAChR function on MS/DB cholinergic neurons but not function of homomeric $\alpha 7$-nAChRs on VTA DAergic neurons.

Concentration- and form-dependent inhibition by $\mathrm{A} \boldsymbol{\beta}_{1-42}$ of $\alpha 7 \beta 2-n A C h R$ function on basal forebrain cholinergic neurons

Our previous studies indicated that $\alpha 4 \beta 2$-nAChRs were more sensitive to $\mathrm{A} \beta_{1-42}$ than homomeric $\alpha 7$-nAChRs (Wu et al., 2004a). Concentration dependence of effects of $A \beta_{1-42}$ on choline-induced currents in $\mathrm{MS} / \mathrm{DB}$ neurons was evident, with effects being negligible at $0.1 \mathrm{~nm}$ and effects at $1 \mathrm{~nm}$ being approximately half of those observed for $10 \mathrm{~nm}$ peptide (Fig. 6A). The magnitude of inhibition apparently had not yet reached maximum after $10 \mathrm{~min}$ of peptide exposure. We also asked which form(s) of $\mathrm{A} \beta_{1-42}$ showed the most potent inhibitory effect on choline-induced currents elicited in MS/DB neurons. Using different preparation protocols (see Materials and Methods), we produced $\mathrm{A} \beta_{1-42}$ monomers (peptide dissolved in DMSO), oligomers (peptide dissolved in water), or fibrils (peptides dissolved in water at low $\mathrm{pH}(\mathrm{pH}=6.0)$ and incubated at $37^{\circ} \mathrm{C}$ for $2 \mathrm{~d}$ ). Peptide forms were defined and monitored using AFM (see supplemental Fig. 1, available at www.jneurosci.org as supplemental material). At $1 \mathrm{nM}$, oligomeric $\mathrm{A} \beta_{1-42}$ exhibited the greatest suppression of choline-induced responses, fibrillar $\mathrm{A} \beta$ had weaker inhibitory effect, and monomeric $\mathrm{A} \beta_{1-42}$ failed to suppress cholineinduced responses, indicating form-selective, $A \beta_{1-42}$ inhibition of nAChRs in MS/DB cholinergic neurons. To test whether $\mathrm{A} \beta_{1-42}$ specifically inhibits $\mathrm{nAChRs}$, we also examined the effects of $1 \mathrm{nM}$ $\mathrm{A} \beta_{1-42}$ on GABA- or glutamate-induced currents in rat MS/DB cholinergic neurons, and the results demonstrated that both $\mathrm{GABA}_{\mathrm{A}}$ receptors and ionotropic glutamate receptors were insensitive to inhibition by $1 \mathrm{nM} \mathrm{A} \beta_{1-42}$ even when peptide effects on ACh-induced current were evident (supplemental Fig. 2, available at www.jneurosci.org as supplemental material). Collectively, these results indicate that, under our experimental conditions, pathologically relevant, low nM concentrations of $\mathrm{A} \beta_{1-42}$, especially in an oligomeric form, specifically inhibit function of apparently heteromeric $\alpha 7 \beta 2$ nAChRs, but peptides cannot inhibit function of homomeric $\alpha 7$ nAChRs, $\mathrm{GABA}_{\mathrm{A}}$, or glutamate receptors on $\mathrm{MS} / \mathrm{DB}$ cholinergic neurons.

Heteromeric $\alpha 7 \beta 2-n A C h R s$ heterologously expressed in Xenopus oocytes display slower current kinetics and high sensitivity to $A \boldsymbol{\beta}_{1-42}$

To further investigate features of presumed, novel $\alpha 7 \beta 2$-nAChRs as naturally expressed in basal forebrain cholinergic neurons, we introduced $\mathrm{nAChR} \alpha 7$ subunits alone or in combination with $\beta 2$ subunits into Xenopus oocytes. Compared with homomeric $\alpha 7$ nAChRs (Fig. 7Aa), heteromeric $\alpha 7 \beta 2$-nAChRs expressed in oocytes injected with rat $\mathrm{nAChR} \alpha 7$ and $\beta 2$ subunit cRNAs at a ratio of 1:1 exhibited smaller peak current responses to choline and slower current decay rates (Fig. 7Ab). These results are consistent with a previous report indicating that $\mathrm{nAChR} \alpha 7$ and $\beta 2$ subunits 
A $M S / D B$
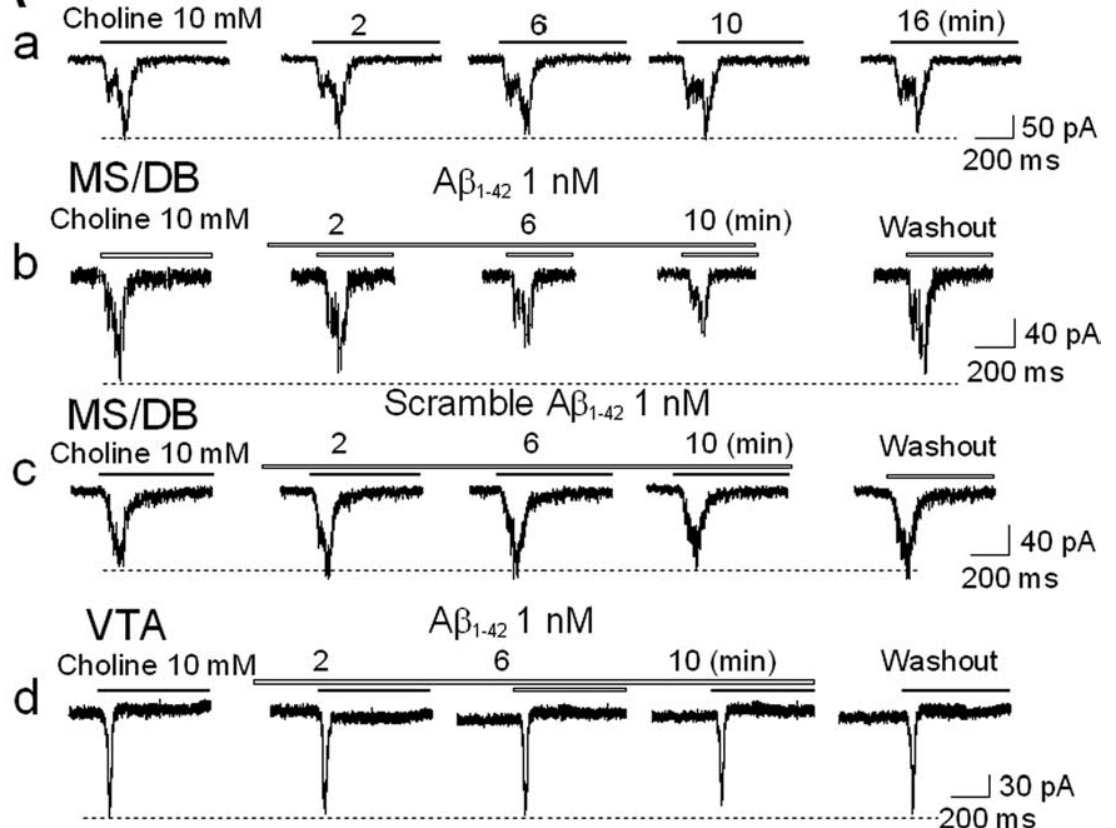

B

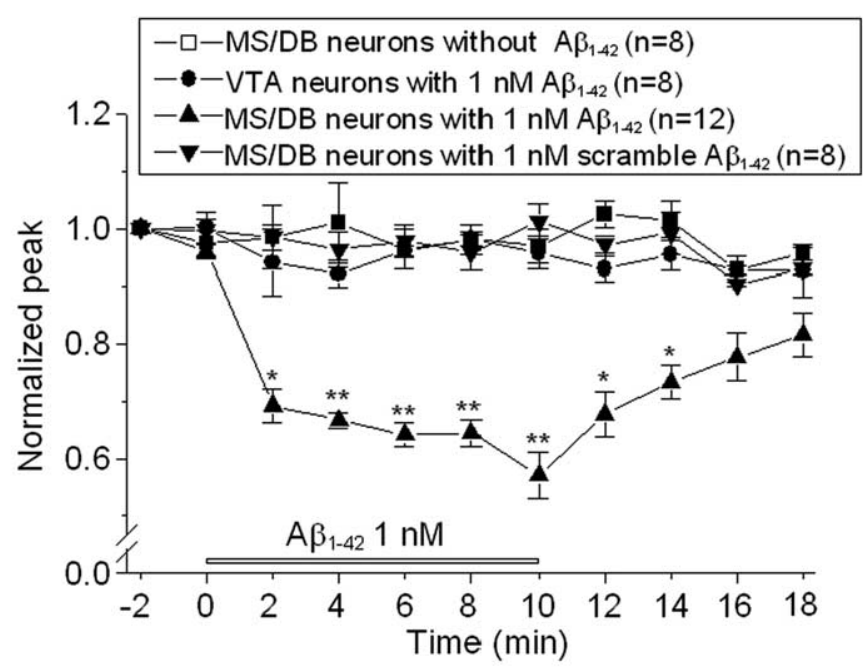

Figure 5. Effects of $1 \mathrm{~nm} A \beta_{1-42}$ on $\alpha 7 \beta 2-n A C h R s$ on MS/DB neurons. Typical whole-cell current traces for responses of $\mathrm{MS} / \mathrm{DB}$ neurons to $10 \mathrm{~mm}$ choline challenge at the indicated times after initial challenge alone show no detectable rundown during repetitive application of agonist ( $2 \mathrm{~s}$ exposure at 2 min intervals; $\boldsymbol{A a}$ ). Choline-induced currents in rat MS/DB neurons were suppressed by $1 \mathrm{~nm} A \beta_{1-42}$ (continuously applied for $10 \mathrm{~min}$, but responses to challenges with choline are shown at the indicated times of $A \beta$ exposure; $\boldsymbol{A} \boldsymbol{b}$ ) but not by $1 \mathrm{~nm}$ scrambled $A \beta_{1-42}$ (as a control; $\boldsymbol{A} \boldsymbol{c}$ ). Choline-induced currents in VTA neurons were not affected by $1 \mathrm{~nm} A \beta_{1-42}(\boldsymbol{A d})$. $\boldsymbol{B}$, Normalized, mean ( $\pm \mathrm{SE}$ ), peak current responses (ordinate) as a function of time (abscissa, min) during challenges with choline alone $(\square)$, in the presence of 1 nм $A \beta(\boldsymbol{\Delta})$, or in the presence of control, scrambled $A \beta(\boldsymbol{\nabla})$ for the indicated numbers of MS/DB neurons, or during challenges with choline in the presence of $1 \mathrm{~nm} A \beta$ for the indicated number of VTA neurons ( ) illustrate that only choline-induced currents in rat MS/DB neurons were sensitive to functional inhibition by $A \beta$. ${ }^{*} p<0.05 ;{ }^{* *} p<0.01$.

can coassemble in the oocyte system to form functional, heteromeric $\alpha 7 \beta 2$-nAChRs (Khiroug et al., 2002). As was the case for comparisons between native $\mathrm{nAChR}$ responses in rat MS/DB or VTA neurons (Fig. 4), sensitivity to functional blockade by MLA was similar for heterologously expressed $\alpha 7 \beta 2$ - or $\alpha 7$-nAChR (supplemental Fig. $3 A-C$, available at www.jneurosci.org as supplemental material). Also similar to the case for native $\mathrm{nAChR}$, heterologously expressed $\alpha 7 \beta 2$-nAChR were more sensitive to blockade by $\mathrm{DH} \beta \mathrm{E}$ than were homomeric $\alpha 7$-nAChR. (Wang et al., 2000)indicates presence of $\beta 2$ subunits with $\alpha 7$ subunits in rodent $\mathrm{MS} / \mathrm{DB}$ neurons. We then tested the sensitivity of heterologously expressed $\alpha 7 \beta 2$-nAChRs in oocytes to $\mathrm{A} \beta$. As was the case for presumed, native $\alpha 7 \beta 2$-nAChRs on $\mathrm{MS} / \mathrm{DB}$ neurons, heterologously expressed heteromeric $\alpha 7 \beta 2$-nAChRs, but not homomeric $\alpha 7$-nAChRs, demonstrated sensitivity to $A \beta_{1-42}(10 \mathrm{nM})$ and insensitivity to $10 \mathrm{nM}$ scrambled $A \beta_{1-42}$ (Fig. $7 B$ ). These results obtained using heterologously expressed $n A C h R s$ again are consistent with the hypothesis that $\mathrm{nAChR} \alpha 7$ and $\beta 2$ subunits likely coassemble and form a unique $\alpha 7 \beta 2$-nAChR that enhances receptor sensitivity to pathologically relevant, low $\mathrm{nm}$ concentrations of $\mathrm{A} \beta_{1-42}$.

\section{Basal forebrain nAChRs in $\mathrm{nAChR} \boldsymbol{\beta 2}$ subunit-null mice do not show coimmunoprecipitation of $\mathrm{nAChR} \alpha 7$ and $\beta 2$ subunits, exhibit fast whole-cell current kinetics, and show low sensitivity to $A \boldsymbol{\beta}_{1-42}$}

As another test of our hypothesis that basal forebrain cholinergic neurons express novel $\alpha 7 \beta 2$-nAChRs, we used wild-type and nAChR $\beta 2$ subunit knock-out $\left(\beta 2^{-/-}\right)$ mice. PCR genotyping was used to identify wild-type or $\beta 2^{-1-}$ mice (Fig. $8 A, B$ ). Using the immunoprecipitation protocol previously described and protein extracts from the MS/DB, nAChR $\beta 2$ subunits were found to coprecipitate with $\mathrm{nAChR} \alpha 7$ subunits only for samples from wild-type but not from $\beta 2^{-1-}$ mice (Fig. 3E, right). Cholineinduced currents in MS/DB cholinergic neurons dissociated from $\beta 2^{-/-}$mice exhibited higher current amplitude, faster kinetics (Fig. 8C), and lower sensitivity to $\mathrm{DH} \beta \mathrm{E}$ (Fig. $8 D a-c$ ) than responses in cholinergic neurons dissociated from wild-type mice. As expected, $1 \mathrm{nM} \mathrm{A} \beta_{1-42}$ failed to suppress choline-induced currents in MS/DB neurons from $\beta 2^{-1-}$ mice but did suppress choline-induced currents in MS/DB neurons from wild-type mice (Fig. $8 E$ ). These results again strongly support the hypothesis that heteromeric, functional $\alpha 7 \beta 2$-nAChRs on basal forebrain MS/DB cholinergic neurons are highly sensitive to a pathologically relevant concentrations of $\mathrm{A} \beta_{1-42}$.

\section{Discussion}

nAChRs in basal forebrain participate in cholinergic transmission and cognitive processes associated with learning and memory (Levin and Rezvani, 2002; Mansvelder et al., 2006). During the early stages of AD, decreases in nAChR-like radioligand binding sites have been observed (Burghaus et al., 2000; Nordberg, 2001), suggesting that nAChR dysfunction could be involved in $\mathrm{AD}$ pathogenesis and cholinergic deficiencies (Nordberg, 2001). Evidence indicates that enhancement of $\alpha 7$-nAChR function protects neurons against $\mathrm{A} \beta$ toxicity 

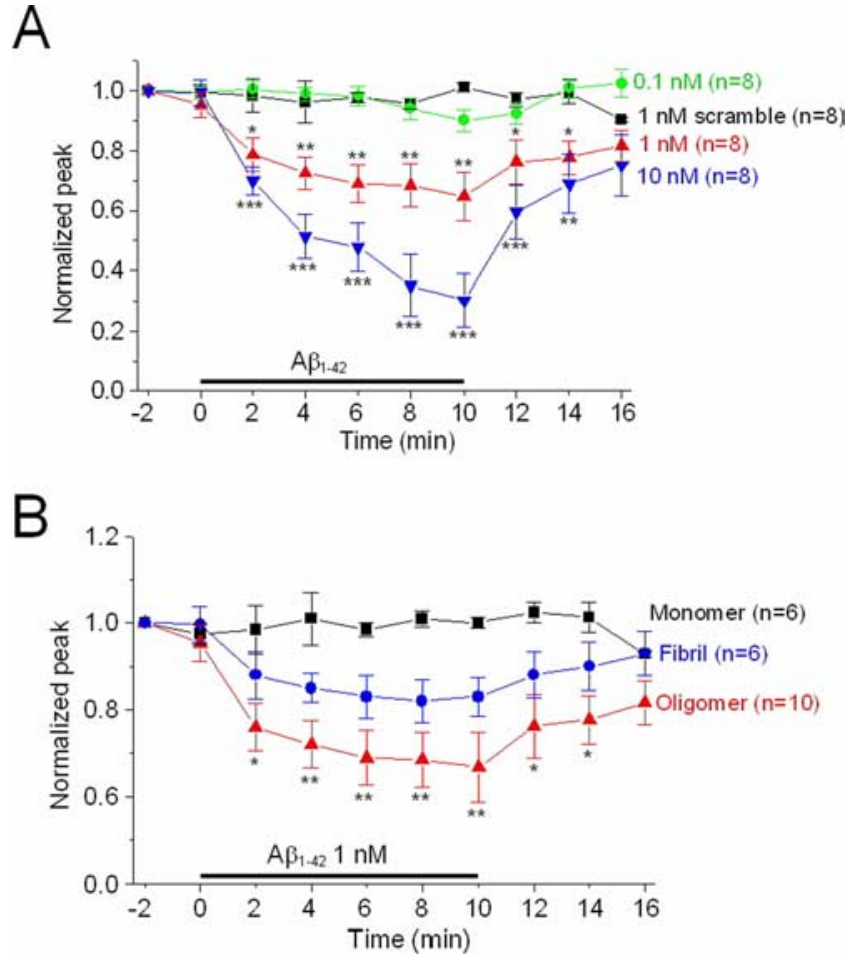

Figure 6. Inhibition of choline-induced currents in dissociated MS/DB neurons by $A \beta_{1-42}$ was concentration and form dependent. $\boldsymbol{A}$, Normalized mean $( \pm \mathrm{SE}$ ) peak current responses (ordinate) of the indicated numbers of MS/DN neurons as a function of time (abscissa, min) during challenges with choline in the presence of $1 \mathrm{~nm}$ scrambled $A \beta(\square)$ or in the presence of $0.1 \mathrm{~nm}(\boldsymbol{O}), 1 \mathrm{~nm}(\boldsymbol{\Delta})$, or $10 \mathrm{~nm}(\boldsymbol{\nabla}) \mathrm{A} \beta$ show concentration dependence of functional block. $\boldsymbol{B}$, Normalized responses (ordinate) during challenges with choline in the presence of $1 \mathrm{~nm} \mathrm{mono-}$ meric $(\square)$, oligomeric $(\boldsymbol{\Delta})$, or fibrillar $(\boldsymbol{O}) A \beta$ indicate insensitivity to monomeric $A \beta$ and highest sensitivity to peptide oligomers. ${ }^{*} p<0.05,{ }^{* *} p<0.01$, and ${ }^{* * *} p<0.001$.

through any or some combination of a number of different mechanisms, as outlined previously (Sadot et al., 1996; Lahiri et al., 2002; Nagele et al., 2002; Geerts, 2005; Q. Liu et al., 2007). On the other hand, pharmacological interventions or diminished $\mathrm{nAChR}$ expression produces learning and memory deficits (Levin and Rezvani, 2002).

The current findings are consistent with the natural expression of a novel, heteromeric, functional $\alpha 7 \beta 2$-nAChR subtype on forebrain cholinergic neurons that is particularly sensitive to functional inhibition by a pathologically relevant concentration ( $1 \mathrm{nM}$ ) of $\mathrm{A} \beta_{1-42}$. Some previous studies investigating the acute effects of $A \beta_{1-42}$ on nAChRs examined receptors on neurons from regions other than the basal forebrain or that were heterologously expressed (Liu et al., 2001; Pettit et al., 2001; Grassi et al., 2003; Wu et al., 2004a; Lamb et al., 2005; Pym et al., 2005) and/or used $\mathrm{A} \beta$ peptides at concentrations (between $100 \mathrm{~nm}$ and $10 \mu \mathrm{M}$ ) that greatly exceed $\mathrm{A} \beta$ concentrations found in $\mathrm{AD}$ brain (Kuo et al., 2000; Mehta et al., 2000). Other studies identified $\alpha 7$-nAChR-like, ACh-induced currents in MS/DB cholinergic neurons by using slice-patch recordings (Henderson et al., 2005; Thinschmidt et al., 2005) and characterized functional, non- $\alpha 7$ $\mathrm{nAChRs}$ by using acutely dissociated forebrain neurons (Fu and Jhamandas, 2003). Our present study combined whole-cell current recordings from acutely dissociated neurons and investigation of MS/DB cholinergic neuronal nAChRs to identify functional $\mathrm{nAChRs}$ that have some features of receptors containing $\alpha 7$ subunits, but we also found high sensitivity of these nAChRs to low concentrations of $\mathrm{A} \beta_{1-42}$.
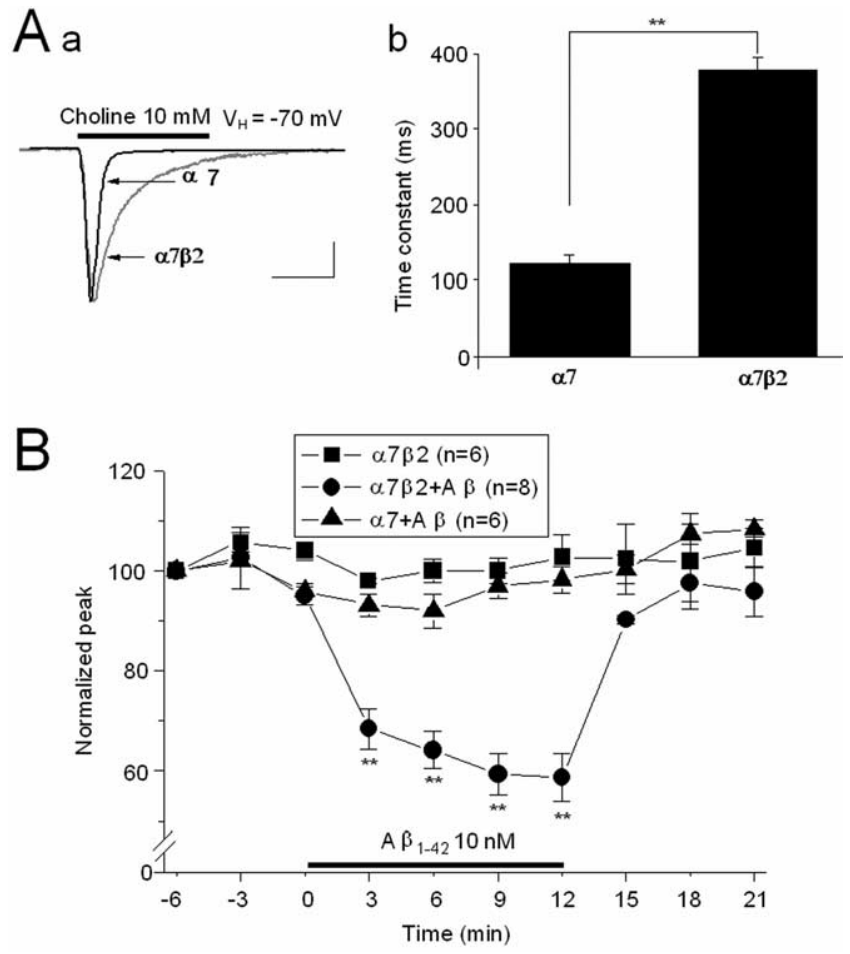

Figure 7. Effects of $A \beta$ on heterologously expressed homomeric $\alpha 7$ - and heteromeric $\alpha 7 \beta 2$-nAChRs in Xenopus 0ocytes. Choline (10 mm, 2 s exposure at 2 min intervals)-induced whole-cell current responses in oocytes injected with rat $\alpha 7-n A C h R$ subunit cRNA alone (Aa, black trace) or with $\alpha 7$ and $\beta 2$ subunit (RNAs at a ratio of 1:1 ( $A a$, gray trace) show slower decay of elicited currents and a longer decay time constant for heteromeric receptors $(\boldsymbol{A} \boldsymbol{a}, \boldsymbol{A b})$. The calibration bars represent $1 \mathrm{~s}$ and $1 \mu \mathrm{A}$ for the $\alpha 7-\mathrm{nAChR}$ response (black trace) and $1 \mathrm{~s}$ and $100 \mathrm{nA}$ for the $\alpha 7 \beta 2$-nAChR response (gray trace), thus also showing that current amplitudes were lower for heteromeric than for homomeric receptors. $V_{H}$, Holding potential. $\boldsymbol{B}$, Normalized mean ( $\pm \mathrm{SE}$ ) peak current responses (ordinate) of the indicated numbers of oocytes heterologously expressing nAChR $\alpha 7$ and $\beta 2$ subunits $(\square, 0)$ or only $\alpha 7$ subunits $(\boldsymbol{\Delta})$ as a function of time (abscissa, min) during challenges with choline alone $(\square)$ or in the presence of $10 \mathrm{~nm} \mathrm{~A} \beta$ $(\boldsymbol{\Delta}, \mathbf{\Delta})$ show sensitivity to functional block by $A \beta$ only for heteromeric receptors. ${ }^{*} p<0.05$, ${ }^{* *} p<0.01$, and ${ }^{* * *} p<0.001$.

Heterologous expression of functional $\alpha 7 \beta 2$-nAChRs with a unique pharmacological profile also has been reported using the Xenopus oocyte expression system (Khiroug et al., 2002). Our results agree with these previous findings and also indicate that functional $\alpha 7 \beta 2$-nAChRs can be heterologously expressed in oocytes. Histological studies have demonstrated coexpression of $\mathrm{nAChR} \alpha 7$ and $\beta 2$ subunits in most forebrain cholinergic neurons (Azam et al., 2003). Our results also are consistent with those observations and show cell-specific, coexpression of nAChR $\alpha 7$ and $\beta 2$ subunits at both message and protein levels. There are other reports (Yu and Role, 1998; El-Hajj et al., 2007) that nAChR $\alpha 7$ subunits could be coassembled with other subunits to form native, heteromeric, $\alpha 7^{\star}$-nAChRs. Our present findings are consistent with those observations.

The notion that the $\mathrm{A} \beta_{1-42}$-sensitive, functional nAChR subtype in MS/DB neurons displaying some features of nAChRs containing $\alpha 7$ subunits, but distinctive from homomeric $\alpha 7$ nAChRs, is composed of $\alpha 7$ and $\beta 2$ subunits, is supported by the loss of $\mathrm{A} \beta$ sensitivity and the conversion of functional $\mathrm{nAChR}$ properties to those like homomeric $\alpha 7$-nAChRs in nAChR $\beta 2$ subunit knock-out animals. It has been reported that there are two isoforms ( $\alpha 7-1$ and $\alpha 7-2$ ) of $\alpha 7$-nAChR transcript in homomeric $\alpha 7$-nAChRs. The $\alpha 7-2$ transcript that contains a novel exon is widely expressed in the brain and showed very slow cur- 

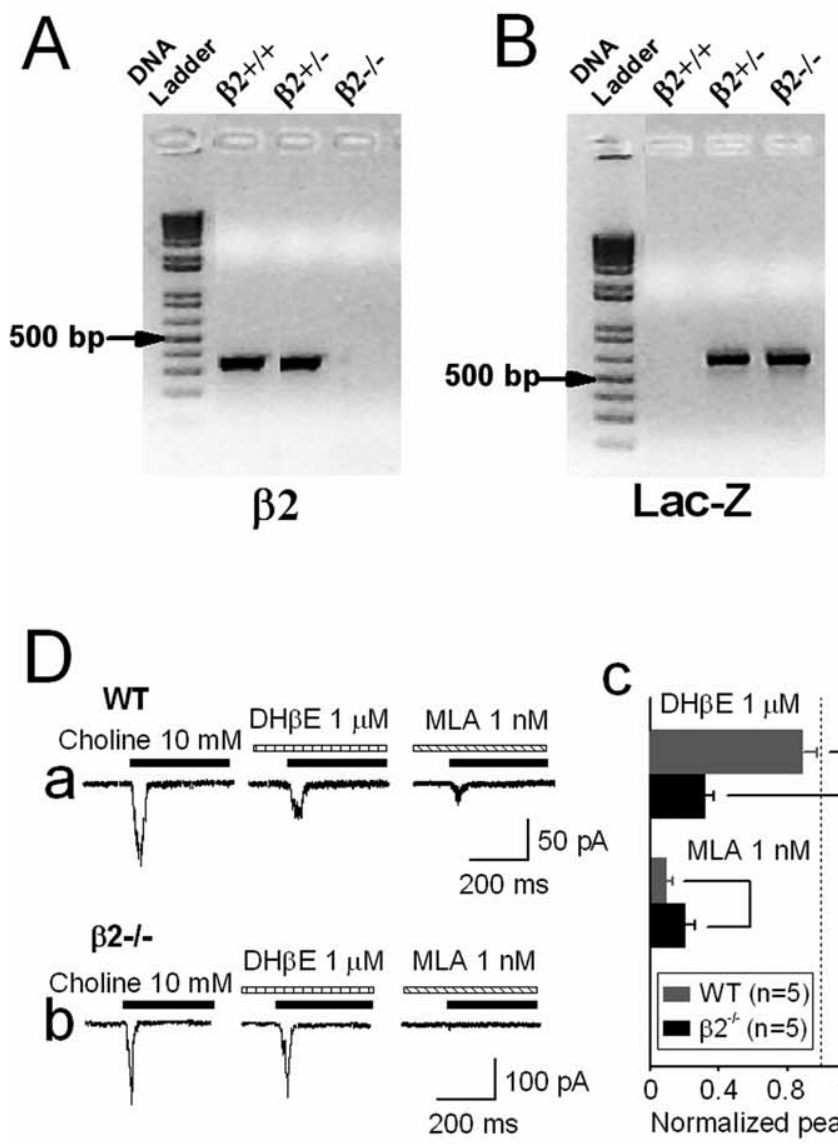

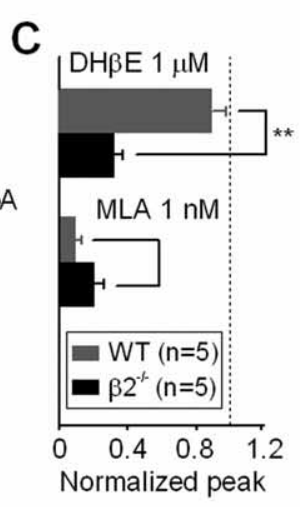

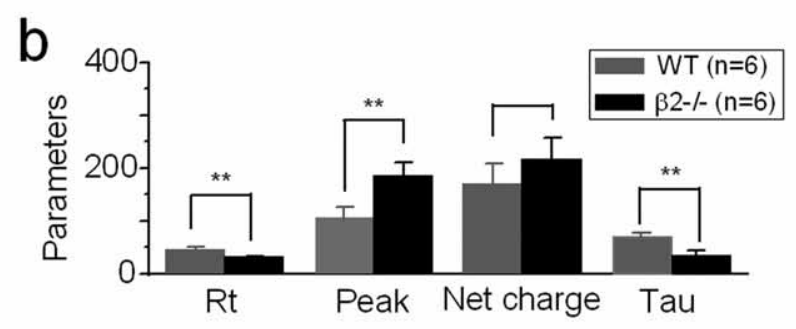

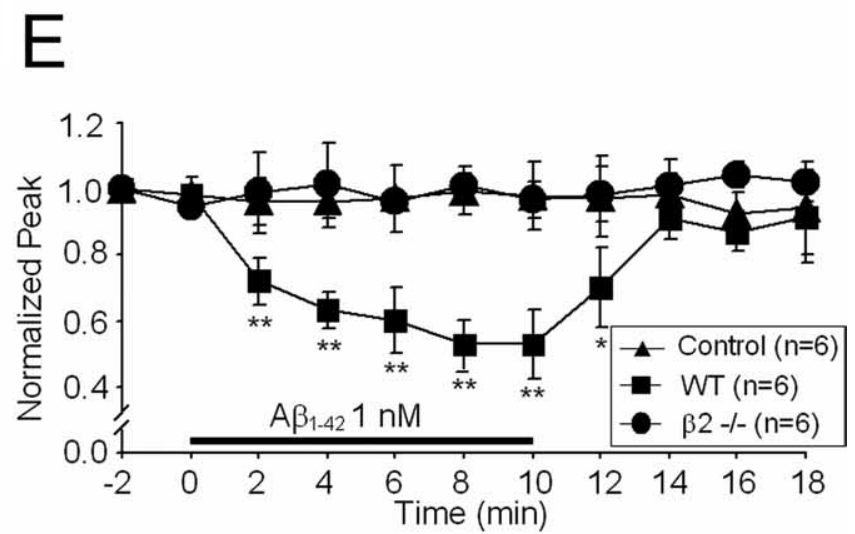

Figure 8. Kinetics, pharmacology, and $A \beta$ sensitivity of $\alpha 7$-containing-nAChRs in $\mathrm{nAChR} \beta 2$ subunit knock-out mice. Genotype analyses demonstrated that nAChR $\beta 2$ subunits are not expressed in $n A C h R ~ \beta 2$ knock-out mice $(\boldsymbol{A})$, whereas Lac-Z (as a marker for the knock-out) was absent in wild-type (WT) mice $(\boldsymbol{B})$. Kinetic analyses showed that whole-cell current kinetics and amplitudes differed for MS/DB neurons from WT compared with nAChR $\beta 2$ subunit knock-out homozygote mice $(\boldsymbol{C} \boldsymbol{a}, \boldsymbol{C} \boldsymbol{b})$. $\mathrm{V}_{\mathrm{H}}$, Holding potential. Compared with MS/DB neurons from WT mice $(\boldsymbol{D a})$, choline-induced currents in MS/DB ( $\boldsymbol{D b}$ ) neurons from $\beta 2$ knock-outs were insensitive to $\mathrm{DH} \beta$ Ebut retained sensitivity to $\mathrm{MLA}(\boldsymbol{D} \boldsymbol{c})$. $A \beta_{1-42}(1 \mathrm{nM})$ suppressed choline-induced currents in MS/DB neurons from WT $(\square)$ but not from $\beta 2$ knock-out $(\boldsymbol{O})$ mice $(\boldsymbol{E})$. "Control" responses $(\boldsymbol{\Delta})$ were choline-induced currents in neurons from WT mice without exposure to $A \beta_{1-42} \cdot{ }^{*} p<0.05$, ${ }^{* *} p<0.01$.

rent kinetics (Saragoza et al., 2003; Severance and Cuevas, 2004; Severance et al., 2004). However, we contend that the heteromeric, presumed $\alpha 7 \beta 2-\mathrm{nAChR}$ described in the present study and expressed in MS/DB neurons is not a homomeric nAChR composed of or containing the $\alpha$ 7-2 transcript for three reasons: (1) in $\beta 2^{-/-}$mice, $\alpha 7$-nAChR-like whole-cell current responses to choline acquire fast kinetic characteristics like those of $\alpha 7$ nAChR responses in VTA neurons, (2) immunoprecipitationWestern blot analyses show coassembly of $\alpha 7$ and $\beta 2$ subunits from the MS/DB but not from the VTA, nor from the MS/DB of $\beta 2^{-1-}$ mice, and (3) pharmacologically, apparently heteromeric $\alpha 7 \beta 2$-nAChRs were sensitive not only to MLA, but also to $\mathrm{DH} \beta \mathrm{E}$.

A recent study suggested that levels of oligomeric forms of $\mathrm{A} \beta_{1-42}$, rather than monomers or $\mathrm{A} \beta$ fibrils, most closely correlate with cognitive dysfunction in animal models of $\mathrm{AD}$ (Haass and Selkoe, 2007). Our current findings also suggest that $A \beta$ oligomers have the most profound effects on $\mathrm{nAChR}$ function, thus extending our earlier studies of $\mathrm{A} \beta$-nAChR interactions (Wu et al., 2004a) and perhaps illuminating why there have been apparent discrepancies in some of the earlier work concerning $\mathrm{A} \beta$-nAChR interactions.

Alzheimer's disease (AD) is a dementing, neurodegenerative disorder characterized by accumulation of amyloid $\beta(\mathrm{A} \beta)$ peptide-containing neuritic plaques, degeneration of basal fore- brain cholinergic neurons, and gradually impaired learning and memory (Selkoe, 1999). The extent of learning and memory deficits in $\mathrm{AD}$ is proportional to the degree of forebrain cholinergic neuronal degeneration, and the extent of $\mathrm{A} \beta$ deposition is used to characterize disease severity (Selkoe, 1999). Processes such as impairment of neurotrophic support and disorders in glucose metabolism have been implicated in cholinergic neuronal loss and AD (Dolezal and Kasparová, 2003). However, clear neurotoxic effects of $\mathrm{A} \beta$ across a range of in vivo and in vitro models suggest that $\mathrm{A} \beta$ plays potentially causal roles in cholinergic neuronal degeneration and consequent learning and memory deficits (Selkoe, 1999).

Although the "cholinergic hypothesis" of AD etiopathogenesis was established in the 1990s, the exact mechanism(s) by which $\mathrm{A} \beta$ accumulation harms cholinergic neurons and results in learning and memory deficits is largely unclear. Seemingly contradictory findings about the effects of $\mathrm{A} \beta$ on function of $\mathrm{nAChRs}$ (Liu et al., 2001; Pettit et al., 2001; Dineley et al., 2002b; Dougherty et al., 2003; Fu and Jhamandas, 2003; Wu et al., 2004a) have been hard to reconcile, although they may be explained by the use of different experimental preparations and different or nonpathologically relevant concentrations or forms of $A \beta$. Other studies indicate that $\alpha 7-\mathrm{nAChR}$ expression is increased in both an AD animal model and in human AD (Dineley et al., 2002a; Counts et al., 2007), suggesting that pathologically relevant con- 
centrations of $\mathrm{A} \beta_{1-42}$ upregulate $\alpha 7 \beta 2$-nAChRs, potentially leading to cholinergic neuronal dysfunction due to abnormal accumulation of intracellular $\mathrm{Ca}^{2+}$. Although this all might occur as a consequence of acute suppression of $\alpha 7 \beta 2$-nAChR function by $\mathrm{A} \beta$, the present studies did not assess this possibility.

Based on the current findings, we suggest that selective, highaffinity effects of oligomeric $A \beta_{1-42}$ on basal forebrain, cholinergic neuronal $\alpha 7 \beta 2$-nAChRs could acutely contribute to disruption of cholinergic signaling and diminished learning and memory abilities (Yan and Feng, 2004). Moreover, to the extent that basal forebrain cholinergic neuronal health requires activity of $\alpha 7 \beta 2$-nAChRs, inhibition of $\alpha 7 \beta 2$-nAChR function by oligomeric $\mathrm{A} \beta_{1-42}$ could lead to losses of trophic support for those neurons and/or their targets, and cross-catalyzed spirals of receptor functional loss and neuronal degeneration also could contribute to the progression of AD. Drugs targeting $\alpha 7 \beta 2$-nAChRs to protect them against $\mathrm{A} \beta$ effects or restoration of $\alpha 7 \beta 2$-nAChR function in cholinergic forebrain neurons could be viable tertiary or even primary therapies for AD.

\section{References}

Azam L, Winzer-Serhan U, Leslie FM (2003) Co-expression of alpha7 and beta2 nicotinic acetylcholine receptor subunit mRNAs within rat brain cholinergic neurons. Neuroscience 119:965-977.

Burghaus L, Schütz U, Krempel U, de Vos RA, Jansen Steur EN, Wevers A, Lindstrom J, Schröder H (2000) Quantitative assessment of nicotinic acetylcholine receptor proteins in the cerebral cortex of Alzheimer patients. Brain Res Mol Brain Res 76:385-388.

Counts SE, He B, Che S, Ikonomovic MD, DeKosky ST, Ginsberg SD, Mufson EJ (2007) Alpha7 nicotinic receptor up-regulation in cholinergic basal forebrain neurons in Alzheimer disease. Arch Neurol 64:1771-1776.

Dineley KT, Xia X, Bui D, Sweatt JD, Zheng H (2002a) Accelerated plaque accumulation, associative learning deficits, and up-regulation of alpha 7 nicotinic receptor protein in transgenic mice co-expressing mutant human presenilin 1 and amyloid precursor proteins. J Biol Chem 277:22768-22780.

Dineley KT, Bell KA, Bui D, Sweatt JD (2002b) beta-Amyloid peptide activates alpha 7 nicotinic acetylcholine receptors expressed in Xenopus oocytes. J Biol Chem 277:25056-25061.

Dolezal V, Kasparová J (2003) $\beta$-Amyloid and cholinergic neurons. Neurochem Res 28:499-506.

Dougherty JJ, Wu J, Nichols RA (2003) $\beta$-Amyloid regulation of presynaptic nicotinic receptors in rat hippocampus and neocortex. J Neurosci 23:6740-6747.

El-Hajj RA, McKay SB, McKay DB (2007) Pharmacological and immunological identification of native alpha7 nicotinic receptors: evidence for homomeric and heteromeric alpha7 receptors. Life Sci 81:1317-1322.

Flores CM, Rogers SW, Pabreza LA, Wolfe BB, Kellar KJ (1992) A subtype of nicotinic cholinergic receptor in rat brain is composed of alpha 4 and beta 2 subunits and is up-regulated by chronic nicotine treatment. Mol Pharmacol 41:31-37.

Fu W, Jhamandas JH (2003) $\beta$-Amyloid peptide activates non-alpha7 nicotinic acetylcholine receptors in rat basal forebrain neurons. J Neurophysiol 90:3130-3136.

Geerts H (2005) Indicators of neuroprotection with galantamine. Brain Res Bull 64:519-524.

Gopalakrishnan M, Monteggia LM, Anderson DJ, Molinari EJ, PiattoniKaplan M, Donnelly-Roberts D, Arneric SP, Sullivan JP (1996) Stable expression, pharmacologic properties and regulation of the human neuronal nicotinic acetylcholine alpha 4 beta 2 receptor. J Pharmacol Exp Ther 276:289-297.

Grassi F, Palma E, Tonini R, Amici M, Ballivet M, Eusebi F (2003) Amyloid beta(1-42) peptide alters the gating of human and mouse alphabungarotoxin-sensitive nicotinic receptors. J Physiol 547:147-157.

Haass C, Selkoe DJ (2007) Soluble protein oligomers in neurodegeneration: lessons from the Alzheimer's amyloid beta-peptide. Nat Rev Mol Cell Biol 8:101-112.

Henderson Z, Boros A, Janzso G, Westwood AJ, Monyer H, Halasy K (2005) Somato-dendritic nicotinic receptor responses recorded in vitro from the medial septal diagonal band complex of the rodent. J Physiol 562:165-182.

Horn R, Marty A (1988) Muscarinic activation of ionic currents measured by a new whole-cell recording method. J Gen Physiol 92:145-159.

Jensen AA, Frølund B, Liljefors T, Krogsgaard-Larsen P (2005) Neuronal nicotinic acetylcholine receptors: structural revelations, target identifications, and therapeutic inspirations. J Med Chem 48:4705-4745.

Khiroug SS, Harkness PC, Lamb PW, Sudweeks SN, Khiroug L, Millar NS, Yakel JL (2002) Rat nicotinic ACh receptor alpha7 and beta2 subunits co-assemble to form functional heteromeric nicotinic receptor channels. J Physiol 540:425-434.

Kuo YM, Kokjohn TA, Watson MD, Woods AS, Cotter RJ, Sue LI, Kalback WM, Emmerling MR, Beach TG, Roher AE (2000) Elevated abeta42 in skeletal muscle of Alzheimer disease patients suggests peripheral alterations of AbetaPP metabolism. Am J Pathol 156:797-805.

Lahiri DK, Utsuki T, Chen D, Farlow MR, Shoaib M, Ingram DK, Greig NH (2002) Nicotine reduces the secretion of Alzheimer's beta-amyloid precursor protein containing beta-amyloid peptide in the rat without altering synaptic proteins. Ann N Y Acad Sci 965:364-372.

Lamb PW, Melton MA, Yakel JL (2005) Inhibition of neuronal nicotinic acetylcholine receptor channels expressed in Xenopus oocytes by betaamyloid1-42 peptide. J Mol Neurosci 27:13-21.

Levin ED, Rezvani AH (2002) Nicotinic treatment for cognitive dysfunction. Curr Drug Targets CNS Neurol Disord 1:423-431.

Lindstrom J (1996) Neuronal nicotinic acetylcholine receptors. Ion Channels 4:377-450.

Lindstrom J, Anand R, Gerzanich V, Peng X, Wang F, Wells G (1996) Structure and function of neuronal nicotinic acetylcholine receptors. Prog Brain Res 109:125-137.

Liu Q, Kawai H, Berg DK (2001) beta-Amyloid peptide blocks the response of alpha 7-containing nicotinic receptors on hippocampal neurons. Proc Natl Acad Sci U S A 98:4734-4739.

Liu Q, Zhang J, Zhu H, Qin C, Chen Q, Zhao B (2007) Dissecting the signaling pathway of nicotine-mediated neuroprotection in a mouse Alzheimer disease model. FASEB J 21:61-73.

Liu Z, Zhang J, Berg DK (2007) Role of endogenous nicotinic signaling in guiding neuronal development. Biochem Pharmacol 74:1112-1119.

Lukas RJ, Changeux JP, Le Novère N, Albuquerque EX, Balfour DJ, Berg DK, Bertrand D, Chiappinelli VA, Clarke PB, Collins AC, Dani JA, Grady SR, Kellar KJ, Lindstrom JM, Marks MJ, Quik M, Taylor PW, Wonnacott S (1999) International Union of Pharmacology. XX. Current status of the nomenclature for nicotinic acetylcholine receptors and their subunits. Pharmacol Rev 51:397-401.

Mansvelder HD, van Aerde KI, Couey JJ, Brussaard AB (2006) Nicotinic modulation of neuronal networks: from receptors to cognition. Psychopharmacology 184:292-305.

Mehta PD, Pirttilä T, Mehta SP, Sersen EA, Aisen PS, Wisniewski HM (2000) Plasma and cerebrospinal fluid levels of amyloid beta proteins 1-40 and 1-42 in Alzheimer disease. Arch Neurol 57:100-105.

Moser N, Mechawar N, Jones I, Gochberg-Sarver A, Orr-Urtreger A, Plomann M, Salas R, Molles B, Marubio L, Roth U, Maskos U, WinzerSerhan U, Bourgeois JP, Le Sourd AM, De Biasi M, Schröder H, Lindstrom J, Maelicke A, Changeux JP, Wevers A (2007) Evaluating the suitability of nicotinic acetylcholine receptor antibodies for standard immunodetection procedures. J Neurochem 102:479-492.

Mudo G, Belluardo N, Fuxe K (2007) Nicotinic receptor agonists as neuroprotective/neurotrophic drugs. Progress in molecular mechanisms. J Neural Transm 114:135-147.

Nagele RG, D'Andrea MR, Anderson WJ, Wang HY (2002) Intracellular accumulation of beta-amyloid(1-42) in neurons is facilitated by the alpha 7 nicotinic acetylcholine receptor in Alzheimer's disease. Neuroscience 110:199-211.

Nordberg A (2001) Nicotinic receptor abnormalities of Alzheimer's disease: therapeutic implications. Biol Psychiatry 49:200-210.

Paxinos G, Watson C (1986) The rat brain in stereotaxic coordinates. Orlando, FL: Academic.

Pettit DL, Shao Z, Yakel JL (2001) $\beta$-Amyloid ${ }_{1-42}$ peptide directly modulates nicotinic receptors in the rat hippocampal slice. J Neurosci 21:RC120(1-5).

Pym L, Kemp M, Raymond-Delpech V, Buckingham S, Boyd CA, Sattelle D (2005) Subtype-specific actions of beta-amyloid peptides on recombinant human neuronal nicotinic acetylcholine receptors (alpha7, 
alpha4beta2, alpha3beta4) expressed in Xenopus laevis oocytes. Br J Pharmacol 146:964-971.

Sadot E, Gurwitz D, Barg J, Behar L, Ginzburg I, Fisher A (1996) Activation of $\mathrm{m} 1$ muscarinic acetylcholine receptor regulates tau phosphorylation in transfected PC12 cells. J Neurochem 66:877-880.

Saragoza PA, Modir JG, Goel N, French KL, Li L, Nowak MW, Stitzel JA (2003) Identification of an alternatively processed nicotinic receptor alpha7 subunit RNA in mouse brain. Brain Res Mol Brain Res 117:15-26.

Selkoe DJ (1999) Translating cell biology into therapeutic advances in Alzheimer's disease. Nature 399:A23-31.

Severance EG, Cuevas J (2004) Distribution and synaptic localization of nicotinic acetylcholine receptors containing a novel alpha7 subunit isoform in embryonic rat cortical neurons. Neurosci Lett 372:104-109.

Severance EG, Zhang H, Cruz Y, Pakhlevaniants S, Hadley SH, Amin J, Wecker L, Reed C, Cuevas J (2004) The alpha7 nicotinic acetylcholine receptor subunit exists in two isoforms that contribute to functional ligand-gated ion channels. Mol Pharmacol 66:420-429.

Sivaprakasam K (2006) Towards a unifying hypothesis of Alzheimer's disease: cholinergic system linked to plaques, tangles and neuroinflammation. Curr Med Chem 13:2179-2188.

Thinschmidt JS, Frazier CJ, King MA, Meyer EM, Papke RL (2005) Medial septal/diagonal band cells express multiple functional nicotinic receptor subtypes that are correlated with firing frequency. Neurosci Lett 389:163-168.
Wang HY, Lee DH, D’Andrea MR, Peterson PA, Shank RP, Reitz AB (2000) beta-Amyloid(1-42) binds to alpha7 nicotinic acetylcholine receptor with high affinity. Implications for Alzheimer's disease pathology. J Biol Chem 275:5626-5632.

Whiting PJ, Schoepfer R, Swanson LW, Simmons DM, Lindstrom JM (1987) Functional acetylcholine receptor in PC12 cells reacts with a monoclonal antibody to brain nicotinic receptors. Nature 327:515-518.

Wu J, Chan P, Schroeder KM, Ellsworth K, Partridge LD (2002) 1-Methyl4-phenylpridinium (MPP+)-induced functional run-down of GABA(A) receptor-mediated currents in acutely dissociated dopaminergic neurons. J Neurochem 83:87-99.

Wu J, Kuo YP, George AA, Xu L, Hu J, Lukas RJ (2004a) beta-Amyloid directly inhibits human alpha4beta2-nicotinic acetylcholine receptors heterologously expressed in human SH-EP1 cells. J Biol Chem 279:37842-37851.

Wu J, George AA, Schroeder KM, Xu L, Marxer-Miller S, Lucero L, Lukas RJ (2004b) Electrophysiological, pharmacological, and molecular evidence for alpha7-nicotinic acetylcholine receptors in rat midbrain dopamine neurons. J Pharmacol Exp Ther 311:80-91.

Yan Z, Feng J (2004) Alzheimer's disease: interactions between cholinergic functions and beta-amyloid. Curr Alzheimer Res 1:241-248.

Yu CR, Role LW (1998) Functional contribution of the alpha5 subunit to neuronal nicotinic channels expressed by chick sympathetic ganglion neurones. J Physiol 509:667-681. 